\title{
Nitrogen leaching from natural ecosystems under global change: a modelling study
}

\author{
Maarten C. Braakhekke ${ }^{1,2}$, Karin T. Rebel ${ }^{1}$, Stefan C. Dekker ${ }^{1}$, Benjamin Smith ${ }^{3}$, \\ Arthur H. W. Beusen ${ }^{2,4}$, and Martin J. Wassen ${ }^{1}$ \\ ${ }^{1}$ Copernicus Institute of Sustainable Development, Faculty of Geosciences, Utrecht \\ University, Heidelberglaan 2, 3584 CS, Utrecht, the Netherlands \\ ${ }^{2}$ PBL Netherlands Environmental Assessment Agency, Postbus 30314, 2500 GH, The Hague, the Netherlands \\ ${ }^{3}$ Department of Physical Geography and Ecosystem Science, Lund University, 22362, Lund, Sweden \\ ${ }^{4}$ Department of Earth Sciences, Geochemistry, Faculty of Geosciences, Utrecht \\ University, P.O. Box 80021, 3508 TA, Utrecht, the Netherlands
}

Correspondence: Maarten Braakhekke (maarten.braakhekke@gmail.com) and Karin Rebel (k.t.rebel@uu.nl)

Received: 10 January 2017 - Discussion started: 15 March 2017

Revised: 30 August 2017 - Accepted: 16 September 2017 - Published: 12 December 2017

\begin{abstract}
To study global nitrogen $(\mathrm{N})$ leaching from natural ecosystems under changing $\mathrm{N}$ deposition, climate, and atmospheric $\mathrm{CO}_{2}$, we performed a factorial model experiment for the period 1901-2006 with the $\mathrm{N}$-enabled global terrestrial ecosystem model LPJ-GUESS (Lund-Potsdam-Jena General Ecosystem Simulator). In eight global simulations, we used either the true transient time series of $\mathrm{N}$ deposition, climate, and atmospheric $\mathrm{CO}_{2}$ as input or kept combinations of these drivers constant at initial values. The results show that $\mathrm{N}$ deposition is globally the strongest driver of simulated $\mathrm{N}$ leaching, individually causing an increase of $88 \%$ by 1997-2006 relative to pre-industrial conditions. Climate change led globally to a $31 \%$ increase in $\mathrm{N}$ leaching, but the size and direction of change varied among global regions: leaching generally increased in regions with high soil organic carbon storage and high initial $\mathrm{N}$ status, and decreased in regions with a positive trend in vegetation productivity or decreasing precipitation. Rising atmospheric $\mathrm{CO}_{2}$ generally caused decreased $\mathrm{N}$ leaching ( $33 \%$ globally), with strongest effects in regions with high productivity and $\mathrm{N}$ availability. All drivers combined resulted in a rise of $\mathrm{N}$ leaching by $73 \%$ with strongest increases in Europe, eastern North America and South-East Asia, where $\mathrm{N}$ deposition rates are highest. Decreases in $\mathrm{N}$ leaching were predicted for the Amazon and northern India. We further found that $\mathrm{N}$ loss by fire regionally is a large term in the $\mathrm{N}$ budget, associated with lower $\mathrm{N}$ leaching, particularly in semi-arid biomes. Predicted global $\mathrm{N}$ leaching from natural lands rose from $13.6 \mathrm{Tg} \mathrm{N} \mathrm{yr}^{-1}$ in 1901-1911 to $18.5 \mathrm{Tg} \mathrm{N} \mathrm{yr}^{-1}$ in 1997-2006, accounting for reductions of natural land cover. Ecosystem $\mathrm{N}$ status (quantified as the reduction of vegetation productivity due to $\mathrm{N}$ limitation) shows a similar positive temporal trend but large spatial variability. Interestingly, this variability is more strongly related to vegetation type than $\mathrm{N}$ input. Similarly, the relationship between N status and (relative) $\mathrm{N}$ leaching is highly variable due to confounding factors such as soil water fluxes, fire occurrence, and growing season length. Nevertheless, our results suggest that regions with very high $\mathrm{N}$ deposition rates are approaching a state of $\mathrm{N}$ saturation.
\end{abstract}




\section{Introduction}

During the last century, availability of mineral nitrogen (N) for ecosystems across the globe has risen dramatically, mainly due to production and application of fertilizers and increasing atmospheric deposition, caused by $\mathrm{N}$ emission from fossil fuel combustion and agriculture (Bouwman et al., 2013b; Galloway et al., 2004). This increased N availability is thought to enhance terrestrial productivity and carbon uptake by relieving $\mathrm{N}$ limitation of natural ecosystems (Zaehle and Dalmonech, 2011). Excessive soil $\mathrm{N}$ input may, however, lead to $\mathrm{N}$ export, mainly as nitrate $\left(\mathrm{NO}_{3}^{-}\right)$, to ground and surface water by leaching and lateral runoff. This results in a range of negative impacts on the environment and human health, such as eutrophication of fresh water and coastal ecosystems, fish kills, and reduction of drinking water quality (Rabalais, 2002; Schlesinger, 2009). In regions with severe ground and surface water pollution, most $\mathrm{N}$ export originates from agricultural land (van Egmond et al., 2002); hence these systems have been the focus of studies quantifying $\mathrm{N}$ budgets (e.g. Velthof et al., 2009). From a global perspective, however, natural ecosystems are a considerable source of $\mathrm{N}$ input to the hydrological system (Beusen et al., 2016; van Drecht et al., 2003). In many ecosystems the combined input from biological $\mathrm{N}$ fixation and atmospheric deposition now exceeds the plant and microbial demand, and in some cases rivals fertilizer application in croplands (Dise et al., 2009).

With increasing $\mathrm{N}$ availability, the capacity of ecosystems to retain $\mathrm{N}$ decreases, resulting in larger leaching losses. However, the relationship between $\mathrm{N}$ inputs and mineral $\mathrm{N}$ leaching (hereafter simply "N leaching") is complex and non-linear, depending on factors such as vegetation type, climate, and soil properties. Insights from $\mathrm{N}$ manipulation experiments and measurements along $\mathrm{N}$ deposition gradients have spawned the concept of "N saturation", a state where $\mathrm{N}$ availability exceeds plant and soil microbial demand (Aber et al., 1989; Ågren and Bosatta, 1988). Since temperate forests have seen the largest increases in $\mathrm{N}$ deposition, previous work on $\mathrm{N}$ saturation and leaching has largely focused on these ecosystems. However, $\mathrm{N}$ deposition is spreading to regions that were previously less affected, including boreal, tropical, and (semi-)arid ecosystems (Galloway et al., 2004; Lamarque et al., 2013). Response of $\mathrm{N}$ leaching in these ecosystems is likely to differ from that in temperate forests. For example, in many tropical forests $\mathrm{N}$ is not a limiting nutrient, due to high rates of biological $\mathrm{N}$ fixation and limited phosphorous availability (Vitousek and Howarth, 1991). These ecosystems may thus be naturally close to $\mathrm{N}$ saturation (Matson et al., 2002) and N leaching is likely to be more responsive to changes in deposition (Matson et al., 1999). Grasslands, on the other hand, are usually $\mathrm{N}$ limited, but tend to occur in drier regions, where $\mathrm{N}$ losses are generally dominated by gaseous soil emissions (Bai et al., 2012) and emissions due to fire (Butterbach-Bahl et al., 2011).
Development of future $\mathrm{N}$ leaching is further influenced by global changes that affect terrestrial ecosystems, most importantly rising atmospheric $\mathrm{CO}_{2}$ and temperature. Increasing $\mathrm{CO}_{2}$ concentrations generally stimulate vegetation productivity (Norby and Zak, 2011), leading to increased $\mathrm{N}$ uptake (Finzi et al., 2007) and decreased N leaching (de Graaff et al., 2006; Hagedorn et al., 2000). The effects of higher temperatures on $\mathrm{N}$ leaching are more ambiguous: several warming experiments found a positive effect due to increased $\mathrm{N}$ mineralization (Beier et al., 2008; Rustad et al., 2001). However, the absence of a response (Beier et al., 2008) or even a negative effect due to increased vegetation activity (Patil et al., 2010) have also been observed.

The combined effect of (changes in) drivers as well as ecosystem and soil properties results in complex spatial and temporal patterns of $\mathrm{N}$ leaching rates. Global prognostic models can help understand these patterns since they provide a means of upscaling process understanding from observational and experimental studies in order to assess $\mathrm{N}$ cycling at large spatial scale. Many modelling studies on $\mathrm{N}$ leaching have been presented in the past decades, for both agricultural and natural ecosystems (e.g. Aber et al., 1997; Groenendijk et al., 2005; Li et al., 2006). However, most of these models are computationally intensive and require site-specific calibration; hence they are difficult to apply at global scale. Global prognostic models have been presented by van Drecht et al. (2003) and recently by Beusen et al. (2016), which provide spatially explicit estimates of $\mathrm{N}$ export to the hydrological system by partitioning $\mathrm{N}$ budgets into various flows, including leaching. While informative, these approaches rely on an equilibrium representation of terrestrial ecosystems and thus cannot represent changes in ecosystem $\mathrm{N}$ storage and $\mathrm{N}$ status. In this context, global terrestrial ecosystem models that explicitly include $\mathrm{N}$ cycling represent a complementary alternative. While less suited for site-level application, these models include the most important ecological processes and feedbacks that influence $\mathrm{N}$ leaching, and are thus useful for examining spatial and temporal patterns and sensitivity to environmental factors. The main motivation to develop coupled $\mathrm{C}-\mathrm{N}$ models has been to represent the constraint of $\mathrm{N}$ limitation on vegetation productivity and land $\mathrm{C}$ uptake (Zaehle and Dalmonech, 2011). Evaluation and application has therefore focused on variables related to $\mathrm{C}$ cycling (e.g. primary productivity, $\mathrm{N}$ use efficiency) rather than $\mathrm{N}$ cycling. $\mathrm{N}$ leaching, while sometimes reported in global modelling studies, does generally not receive specific attention (Gerber et al., 2010; Jain et al., 2009; Smith et al., 2014; Zaehle et al., 2014).

This paper presents a global modelling study of $\mathrm{N}$ leaching from natural ecosystems. Specifically, we focus on temporal changes during the last century in relation to change of environmental drivers, as well as spatial patterns of contemporary $\mathrm{N}$ leaching rates. We aimed to answer the following questions: (1) what is the effect of environmental drivers, most importantly $\mathrm{N}$ deposition, climate, and atmospheric $\mathrm{CO}_{2}$ 
concentration, on $\mathrm{N}$ leaching from natural ecosystems, and (2) what is the current $\mathrm{N}$ status of natural ecosystems? We used LPJ-GUESS, a dynamic vegetation/ecosystem model optimized for regional and global studies that simulates terrestrial vegetation dynamics and biogeochemical cycles. The model has recently been extended to represent plant and soil $\mathrm{N}$ cycling and $\mathrm{N}$ limitations on plant productivity and carbon fluxes (Smith et al., 2014). The N-enabled version has been tested based on both site-level and regional observations (Smith et al., 2014; Wårlind et al., 2014) and includes the main processes underlying large-scale patterns and global trends at decadal to centennial timescale of $\mathrm{N}$ leaching in response to drivers, which is the focus of this study. We present results from a global historical simulation, focusing on natural vegetation for the period 1901-2006. Predicted vegetation productivity and $\mathrm{N}$ leaching are compared to previously published estimates from measurements and models. Furthermore, to study the individual and combined effects of the main drivers of $\mathrm{N}$ leaching - $\mathrm{N}$ deposition, climate, and atmospheric $\mathrm{CO}_{2}$ - we performed a full factorial experiment in which either the true transient time series was used for these drivers or a trend-free time series, representative of pre-industrial conditions, was used. We discuss the effects of these factors on $\mathrm{N}$ leaching in the context of insights from field observations, manipulation experiments, and other modelling studies.

\section{Methods}

\subsection{LPJ-GUESS}

Here a brief overview of the LPJ-GUESS (Lund-PotsdamJena General Ecosystem Simulator) model is provided, focusing on processes that are most relevant for $\mathrm{N}$ cycling. A complete description of the model can be found in Smith et al. (2014) and references therein, as well as Supplement Text S1.

\subsubsection{General description}

LPJ-GUESS (Smith et al., 2001) simulates vegetation dynamics and biogeochemical fluxes of $\mathrm{C}$ and $\mathrm{N}$ in terrestrial ecosystems and employs generalized biome- or global-scale parameterizations of component ecosystem processes, allowing it to be employed globally or for any large region without recalibration. LPJ-GUESS has been used extensively for studies from site to global scales. It is forced by climate variables, $\mathrm{CO}_{2}$ concentration, and $\mathrm{N}$ deposition, and runs with a daily time step, except for $\mathrm{C}$ allocation, vegetation dynamics, and disturbances, which are resolved annually. Our simulations focused on natural vegetation, i.e. croplands were not considered. Eleven plant functional types (PFTs) were included, representing vegetation in temperate, tropical, and boreal wooded ecosystems and grasslands. The model predicts the occurrence of each PFT based on bioclimatic limits and competition with other PFTs for light and soil resources. Contrary to most global ecosystem models, LPJ-GUESS explicitly represents the age distribution dynamics (demography) of woody PFTs and variations in stand development across landscapes, shown to be important for carbon and nutrient balance (Haverd et al., 2014; Wolf et al., 2011). The model simulates trees of different cohorts (age classes) of cooccurring PFTs, which are each represented by an average individual. Mortality and establishment of the individuals are implemented in a stochastic fashion, as are fire (modelled according to Thonicke et al., 2001) and other disturbances. Sub-grid variability resulting from landscape heterogeneity and differences in disturbance history are accounted for by simulating a predefined number of replicate "patches" (area 0.1 ha) per grid cell. The conditions for all patches within a grid cell are identical but differences arise from the stochastic calculations. Within each patch LPJ-GUESS simulates fluxes of $\mathrm{C}$, water, and $\mathrm{N}$ in vegetation and soil, based on descriptions of the key controlling processes, including photosynthesis, plant $\mathrm{C}$ allocation, autotrophic respiration, evapotranspiration, percolation, lateral runoff, and soil carbon cycling. The soil hydrological calculations are described in more detail in Gerten et al. (2004) and Olin et al. (2015). The simulation is initialized with a 500-year spin-up to accumulate vegetation and soil $\mathrm{C}$ and $\mathrm{N}$ pools in equilibrium with the initial forcing. During this phase, the model is forced by a trend-free time series (here 10 years) of annually varying inputs.

\subsubsection{N cycling module}

In LPJ-GUESS, ecosystem $\mathrm{N}$ is present in vegetation biomass and in the soil in mineral and organic form. In the model version employed for our study, mineral soil $\mathrm{N}$ is represented by a single pool; i.e. different $\mathrm{N}$ species such as ammonium and nitrate, and transformation between these are not distinguished.

Input of $\mathrm{N}$ in natural ecosystems occurs by biological $\mathrm{N}$ fixation and $\mathrm{N}$ deposition. Biological $\mathrm{N}$ fixation (BNF) refers to the uptake of atmospheric $\mathrm{N}_{2}$ and the reduction to ammonia, by free-living soil microorganisms and by symbiotic associations of microorganisms with plants. In LPJ-GUESS, BNF is calculated as a linear function of ecosystem evapotranspiration, following an empirical large-scale relationship identified by Cleveland et al. (1999). $\mathrm{N}$ deposition constitutes the input of reactive $\mathrm{N}$ from the atmosphere to the biosphere as particles (dry deposition) or with precipitation (wet deposition). $\mathrm{N}$ deposition occurs as a range of species, both oxidized and reduced, and is controlled by $\mathrm{N}$ emissions from fossil fuel combustion, agricultural activities, and biomass burning - both natural and human induced. Since the residence times of reactive $\mathrm{N}$ species are relatively short (110 days), $\mathrm{N}$ deposition is a localized issue, and local rates are usually closely related to local emissions. $\mathrm{N}$ deposition rates are part of the model input (see Sect. 2.2). 
$\mathrm{N}$ deposition and BNF are directly added to the soil mineral $\mathrm{N}$ pool. Root uptake transfers $\mathrm{N}$ from the soil mineral $\mathrm{N}$ pool to vegetation on a daily time step. Plants take up $\mathrm{N}$ from the mineral soil pool in order to maintain optimal leaf $\mathrm{N}$ content required for photosynthesis (modelled according to Haxeltine and Prentice, 1996). Following Meyerholt and Zaehle (2015), C-to-N ratio of non-leaf biomass pools is fixed. If insufficient $\mathrm{N}$ is available, the plant experiences $\mathrm{N}$ stress and photosynthesis is reduced. To this end the model calculates an "N limitation factor" equal to the ratio of the true $V_{\max }$ and the $V_{\max }$ in absence of $\mathrm{N}$ limitation (both without water limitation). Here, $V_{\max }$ is the carboxylation capacity of Rubisco. Additionally, different PFT cohorts compete for uptake of soil N, with grass PFTs being more competitive than tree PFTs.

$\mathrm{N}$ stored in vegetation is returned to the soil in organic form in conjunction with biomass turnover due to senescence, mortality, and disturbance. Litter and soil organic matter (SOM) dynamics follow the CENTURY model (Parton et al., 1993). Gaseous $\mathrm{N}$ loss during nitrification and denitrification is accounted for by a $1 \%$ reduction of the daily $\mathrm{N}$ mineralization. Organic $\mathrm{N}$ leaching occurs as a fraction of the soil microbial $\mathrm{N}$ pool, determined by the percolation rate and the soil sand fraction. Mineral $\mathrm{N}$ leaching is calculated as a fraction of the mineral $\mathrm{N}$ pool equal to the relative water loss by percolation and interflow. $\mathrm{N}$ loss due to surface runoff is not considered. Finally, fire events cause loss of vegetation $\mathrm{N}$, assumed to be emitted in gaseous form.

\subsection{Global simulations}

The model was run globally on a $0.5 \times 0.5^{\circ}$ grid. Climate forcing (mean monthly fields of temperature, precipitation, cloud fraction, and number of rain days per month) was taken from the Climate Research Unit (CRU) TS 3.0 data set (Mitchell and Jones, 2005; Supplement Figs. S1b-c, S2, S3), and interpolated to daily values. For precipitation, this was done using a stochastic weather generator, which randomly distributes monthly precipitation over the rain days in each month. For other variables, linear interpolation was used. Atmospheric $\mathrm{CO}_{2}$ concentration was input as global means, varying annually (Fig. S1d). Spatio-temporal fields (interpolated to $0.5 \times 0.5^{\circ}$ resolution) of atmospheric $\mathrm{N}$ deposition were taken from the ACCMIP historical data set (Lamarque et al., 2013; Figs. 1, S1a), which provides annual cycles with monthly time steps in decadal intervals for the period 1850 2010. These data comprise results from an ensemble of simulations with 11 atmospheric chemistry models, and can be assumed to represent the best estimate of global $\mathrm{N}$ deposition currently available. $\mathrm{N}$ input by deposition was not adjusted for leaf morphology.

During the spin-up, the model was run with forcing representing preindustrial conditions: climate data for 1901-1910, detrended and cycled repeatedly, and atmospheric $\mathrm{CO}_{2}$ for 1901 (296 ppmv). Since N deposition has regionally under- (a) Atmospheric $\mathrm{N}$ deposition 2000-2010 (kg N ha $\left.{ }^{-1} \mathrm{yr}^{-1}\right)$

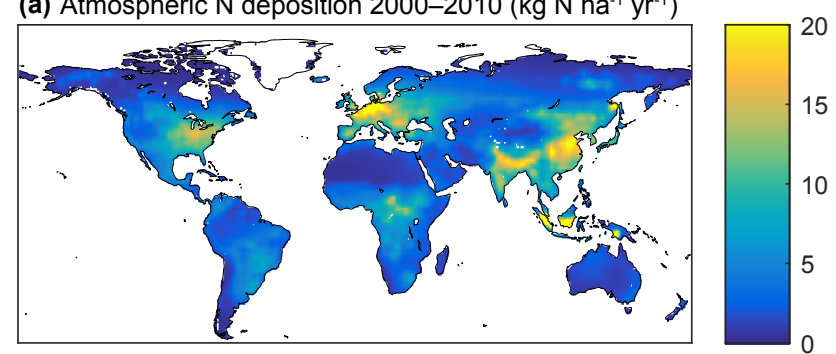

(b) Change relative to $1850-1860\left(\mathrm{~kg} \mathrm{~N} \mathrm{ha}^{-1} \mathrm{yr}^{-1}\right)$

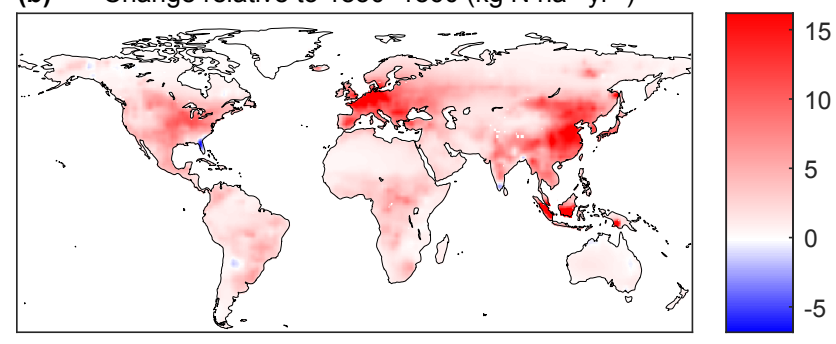

Figure 1. Atmospheric $\mathrm{N}$ deposition for 2000-2010, the last decadal interval of the ACCMIP historic $\mathrm{N}$ deposition data set (Lamarque et al., 2013). (a) Absolute rates. (b) Change relative to 1850-1860. For both figures the colour axis is cut off at approximately the $99 \%$ quantile to improve readability.

gone substantial changes before 1900 due to land-use change related biomass burning, we used $\mathrm{N}$ deposition for the first time step of the ACCMIP data set, 1850-1860, both for the spin-up and the factorial experiment (Sect. 2.3).

\subsection{Factorial experiment}

To disentangle the effects of $\mathrm{N}$ deposition, climate, and atmospheric $\mathrm{CO}_{2}$ concentration on $\mathrm{N}$ leaching, we conducted a series of simulations in which the model was forced either by the true, transient values for these drivers by the or trend-free time series as during the spin-up. We performed a full factorial experiment for the three drivers, resulting in the eight simulations listed in Table 1. Note that for this purpose atmospheric $\mathrm{CO}_{2}$ concentration is not considered a climate variable. Herein we shall refer to simulation $+\mathrm{Ndep}$ $+\operatorname{clim}+\mathrm{CO}_{2}$ as the "true historical simulation", and -Ndep $-\operatorname{clim}-\mathrm{CO}_{2}$ as the "control simulation". These runs were performed with 20 replicate patches (Sect. 2.1.1) and all others with 10 patches to limit computation time. Comparison of results from the simulations in which one factor (e.g. $\mathrm{N}$ deposition) is included to results from the control simulation allows us to study the individual effect of this factor. Similarly, interactions between factors can be studied based on the simulations with two factors included (e.g. $\mathrm{N}$ deposition and $\mathrm{CO}_{2}$ increase). For the analysis of the results we stratified the results by biome. Grid cells were classified into 17 biomes, based on leaf area index of the PFTs and latitude, according to the scheme presented in Smith et al. (2014), which is based on Hickler et al. (2006). 
Table 1. Simulation runs in the factorial simulation experiment. Note that climate comprises four variables (Sect. 2.3).

\begin{tabular}{llll}
\hline Label & N deposition & Climate & Atmospheric \\
\hline -Ndep - clim $-\mathrm{CO}_{2}$ & constant & constant & $\mathrm{CO}_{2}$ constant \\
+Ndep - clim $-\mathrm{CO}_{2}$ & true & constant & constant \\
-Ndep + clim $-\mathrm{CO}_{2}$ & constant & true & constant \\
-Ndep - clim $+\mathrm{CO}_{2}$ & constant & constant & true \\
+Ndep +clim $-\mathrm{CO}_{2}$ & true & true & constant \\
+Ndep - clim $+\mathrm{CO}_{2}$ & true & constant & true \\
-Ndep +clim $+\mathrm{CO}_{2}$ & constant & true & true \\
+ Ndep + clim $+\mathrm{CO}_{2}$ & true & true & true \\
\hline
\end{tabular}

We assess ecosystem $\mathrm{N}$ limitation and saturation based on the $\mathrm{N}$ limitation factor (Sect. 2.1.2). This quantity serves as an indicator of vegetation $\mathrm{N}$ status and ranges between 0 , signifying null Rubisco capacity due to $\mathrm{N}$ limitation, and 1 , signifying optimal Rubisco capacity (no reduction due to $\mathrm{N}$ limitation).

Since the focus of this study is on natural ecosystems, we scale up LPJ-GUESS results to the globe assuming a world with potential natural vegetation. However, when comparing our results to other published estimates we correct them for the fraction of non-natural land based on the land use data set of Hurtt et al. (2011). Models outputs are multiplied by natural land fractions (types "natural" and "barren") on a global $0.5 \times 0.5^{\circ}$ grid.

\subsection{Data used for model evaluation}

To evaluate LPJ-GUESS predictions, we compared several predicted variables to previously published estimates. First, predicted gross primary productivity (GPP) was evaluated based on a data-driven global product from the FLUXCOM data set (Jung et al., 2017; Tramontana et al., 2016). This product was derived by training machine learning (ML) models on eddy-covariance measurements from the FLUXNET data set using meteorological measurements and satellite data as input, and subsequently running these models for a global spatio-temporal grid. Estimates were made with three ML algorithms and two flux-partitioning approaches (Tramontana et al., 2016), resulting in six global products. We compare our results to the mean GPP and use the spread over the different products as a measure of uncertainty. The ML models were trained for 18 land cover types (LCTs) individually which were combined using area fractions of these LCTs, derived from MODIS satellite data. Since we consider natural vegetation only, we derived a modified GPP as the weighted mean over natural land cover types, where the weights are given by the fraction of each LCT in a grid cell divided by summed fraction for all natural LCTs.

Second, $\mathrm{N}$ leaching predictions were compared to estimates from the IMAGE model published by Beusen et al. (2016). Briefly, Beusen et al. modelled $\mathrm{N}$ flows using an equilibrium approach which partitions soil $\mathrm{N}$ input from deposition and fixation to various losses, including surface runoff, denitrification, and leaching. The model also included natural ecosystems, but for the time frame of interest, grid cells were treated as either fully natural or fully anthropogenic. Therefore, we applied the same mask for natural lands to our predictions of $\mathrm{N}$ leaching to improve comparability.

Finally, the fraction of $\mathrm{N}$ lost in gaseous form by denitrification $\left(f_{\text {denit }}\right)$ relative to total $\mathrm{N}$ loss (excluding fire) was compared to two observation-driven data sets derived by Wang et al. (2017) and Goll et al. (2017). These studies both used activity of the stable isotope ${ }^{15} \mathrm{~N}$ in the soil to determine the denitrification fraction, based on a method published by Bai et al. (2012), but differ in their approach to scale $f_{\text {denit }}$ up to the global level. Furthermore, since the isotope approach is mostly suitable for soils under natural vegetation (E. Bai, personal communication, 2017) Wang et al. used IMAGE model to determine $f_{\text {denit }}$ for croplands. Goll et al. (2017) did not treat croplands differently. Since it was not possible to correct the data sets for non-natural land cover, we compare the data sets to the LPJ-GUESS predictions as is. For more information on the observation-based data sets, we refer the reader to the respective publications.

\section{Results}

Presentation of the results focuses on the last 10 years of the simulation (1997-2006), and their comparison to the preindustrial baseline; most graphs (except time series) show model outputs for this period.

\subsection{True historical simulation}

\subsubsection{Ecosystem $\mathrm{N}$ budget}

Figure 1a and b depict contemporary $\mathrm{N}$ deposition (20002006) and changes relative to 1850-1860, respectively. Highest deposition rates occur in the human population centres of western Europe, eastern USA, and South-East Asia (Fig. 1a). Since these regions are generally predicted to have temperate forests (Fig. S4), these biomes have the highest $\mathrm{N}$ deposition and therefore overall $\mathrm{N}$ input (Fig. 2a, temperate broadleaf, deciduous, and mixed forests). The same regions experienced the strongest increase in $\mathrm{N}$ deposition compared to pre-industrial conditions (Fig. 1b). Most of the world has experienced some increase in $\mathrm{N}$ deposition, with a few exceptions, most notably Florida, USA, where an assumed reduction in biomass burning in the $\mathrm{N}$ emission data set used to derive $\mathrm{N}$ deposition leads to reduced $\mathrm{N}$ deposition (van Aardenne et al., 2001; Lamarque et al., 2013). Near the end of the 20th century Indonesia (particularly Kalimantan) shows extremely high $\mathrm{N}$ deposition with rates higher than $100 \mathrm{~kg} \mathrm{~N} \mathrm{ha}^{-1} \mathrm{yr}^{-1}$ (not apparent in Fig. 1 because the colour axis is cut off), a result of high $\mathrm{N}$ emissions caused by the se- 


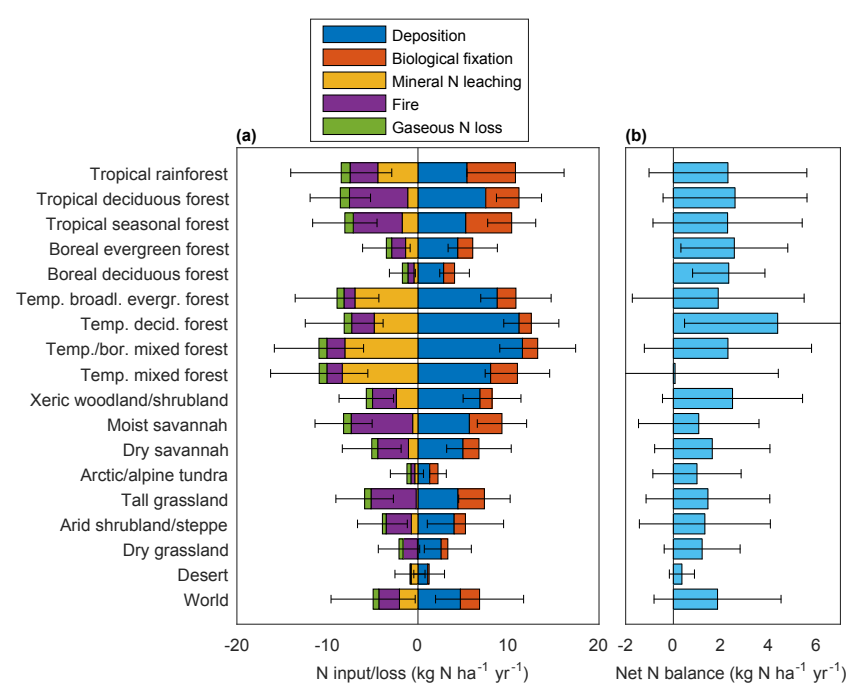

Figure 2. Ecosystem $\mathrm{N}$ budget per biome for the true historical simulation (+Ndep +clim $+\mathrm{CO}_{2}$ ) averaged over the period 19972006. (a) Mean $\mathrm{N}$ input and loss fluxes. (b) Mean net ecosystem exchange of N. Organic N leaching (not shown) is negligible for all biomes. Error bars indicate 1 standard deviation among areaweighted grid cell averages for the target time period.

vere forest fires in Indonesia in 1997 and 1998 (J.-F. Lamarque, personal communication, 2016).

Figure 2 depicts the predicted ecosystem $\mathrm{N}$ budget for the 17 biomes and the world, including the simulated contribution of different export fluxes. Although within-biome variability is large, most biomes differ significantly from others for $\mathrm{N}$ input, $\mathrm{N}$ loss, and $\mathrm{N}$ net ecosystem exchange, as indicated by a Welch's $t$ test (Supplement Tables S1-S3). Figure $2 \mathrm{~b}$ shows that all biomes have an average positive $\mathrm{N}$ net balance over the 1997-2006 period, i.e. they retain N. Biological N fixation (BNF; Fig. S5) is less localized than deposition. Due to the empirical relationship with evapotranspiration assumed by the model of Cleveland et al. (1999), it is predicted to occur most strongly in the tropics, and is almost absent in deserts (Fig. 2a). However, in all biomes BNF is a less important $\mathrm{N}$ source than atmospheric deposition.

The relative contribution of $\mathrm{N}$ leaching, fire, and gaseous $\mathrm{N}$ loss to the total $\mathrm{N}$ loss varies strongly spatially (Fig. 3). $\mathrm{N}$ leaching (further discussed in Sect. 3.1.2) is important in temperate regions and the tropics, mainly due to high inputs. $\mathrm{N}$ leaching also stands out in cold regions, particularly $\mathrm{N}$. America, which is explained by temperature constraint on vegetation productivity. Conversely, in strongly arid regions (e.g. the Sahara) gaseous $\mathrm{N}$ emission dominates (see Fig. 10a), due to low soil water fluxes. Finally, fire is an important $\mathrm{N}$ loss process in semi-arid regions, which mainly comprise grasslands. Predicted organic N leaching (Fig. S6) is generally much lower than mineral $\mathrm{N}$ leaching, and is mostly negligible compared to the overall $\mathrm{N}$ budget.

\subsubsection{Mineral $\mathrm{N}$ leaching and $\mathrm{N}$ status}

Figure $4 \mathrm{a}$ depicts $\mathrm{N}$ leaching for the true historical simulation. The regions where strongest $\mathrm{N}$ leaching rates occur generally correspond with regions of highest $\mathrm{N}$ deposition (Fig. 1). The American and African tropics show moderately high leaching, because of high BNF rates. The highest leaching rates (up to $95 \mathrm{~kg} \mathrm{Nha}^{-1} \mathrm{yr}^{-1}$ ) occur in Indonesia due to the high $\mathrm{N}$ deposition rates for the target period (see Sect. 3.1.1). The spatial patterns in Fig. 4a are largely mirrored by the $\mathrm{N}$ leaching to $\mathrm{N}$ input ratio (Fig. $4 \mathrm{~b}$ ), indicating that with higher $\mathrm{N}$ inputs the relative importance of leaching increases. Exceptions are regions with significant $\mathrm{N}$ losses due to mineralization (e.g. Russia, Canada), as well as cold regions.

Figure 5 shows a global map of the $\mathrm{N}$ limitation factor, serving as an indicator of overall vegetation $\mathrm{N}$ status. It should be noted that in the model $\mathrm{N}$ limitation of photosynthesis is applied before moisture limitation (but after accounting for light and $\mathrm{CO}_{2}$ concentration). Therefore, it is possible that in regions where both factors are limiting additional $\mathrm{N}$ input would not result in higher productivity. Biome dependencies are apparent (see Fig. S4) with grasslands and high-latitude ecosystems having generally strong $\mathrm{N}$ limitation, while temperate forests tend to be closer to $\mathrm{N}$ saturation. Deserts have a wide range of $\mathrm{N}$ status values. The Sahara and North American deserts are predicted to be strongly $\mathrm{N}$ limited. At high latitudes, the model also predicts very low $\mathrm{N}$ status for parts of the tundra and desert biomes. In most cases, within-biome variability is partially explained by $\mathrm{N}$ input (Fig. S8). However, the relationships differ strongly between biomes, and for the dry grassland and desert biomes it is virtually absent. Figure 5 further shows that $\mathrm{N}$ status has risen during the previous century, owing mainly to increasing $\mathrm{N}$ deposition.

$\mathrm{N}$ status has a profound effect on the relationship between $\mathrm{N}$ input and $\mathrm{N}$ leaching per biome (Fig. 6). In strongly $\mathrm{N}-$ limited biomes (tundra, grasslands, and boreal deciduous forest) considerably less $\mathrm{N}$ is lost by leaching than what is input. Semi-arid biomes (tropical deciduous forests, savannahs, and arid shrublands) also leach less $\mathrm{N}$ than they receive. However, this is mainly related to strong $\mathrm{N}$ losses due to fire (see Fig. 3), which keeps these ecosystems continually in an aggrading state. The interaction between $\mathrm{N}$ status, fire, and $\mathrm{N}$ leaching is further illustrated by Fig. 7. The graph suggests a non-linear relationship between $\mathrm{N}$ status and relative leaching losses. However, this apparent non-linearity is mainly caused by biomes with high fire frequency which reduces the ratio of $\mathrm{N}$ leaching to $\mathrm{N}$ inputs. An ancillary simulation run without fire disturbances resulted in a roughly linear relationship (Fig. S14). Figure 7 further confirms the exceptional position of deserts, where $\mathrm{N}$ cycling is mainly determined by physical processes rather than vegetation. 


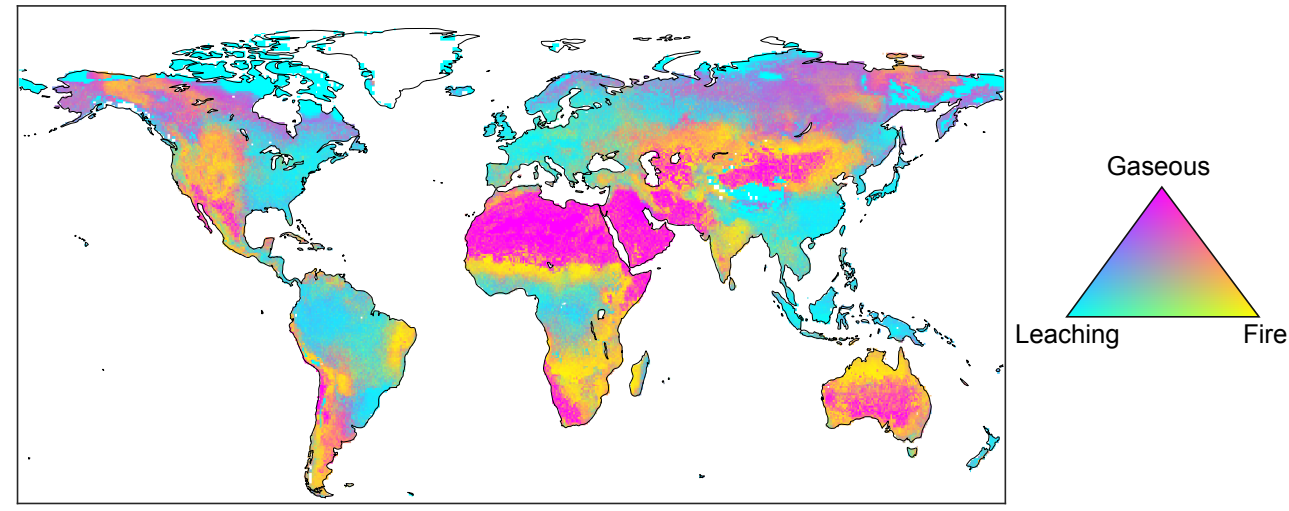

Figure 3. Relative contribution of leaching, gaseous loss, and fire to overall ecosystem $\mathrm{N}$ loss for the true historical simulation (+Ndep + clim $+\mathrm{CO}_{2}$ ) averaged over the period 1997-2006. The colours at the three corners of the triangle indicate $100 \% \mathrm{~N}$ loss by the corresponding process.

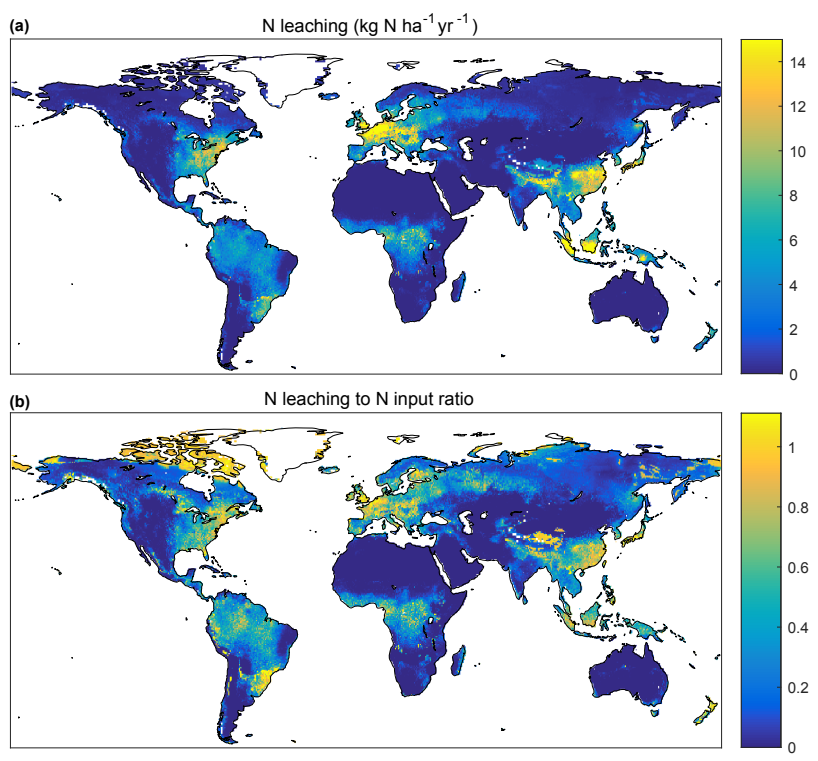

Figure 4. Mineral $\mathrm{N}$ leaching for the true historical simulation (+Ndep + clim $+\mathrm{CO}_{2}$ ) averaged over the period 1997-2006. (a) $\mathrm{N}$ leaching; (b) ratio of $\mathrm{N}$ leaching and $\mathrm{N}$ input ( $\mathrm{N}$ deposition $+\mathrm{BNF}$ ). For readability, the colour axes have been cut off at the $99 \%$ quantile.

\subsubsection{Comparison with previous estimates}

Figure 8 shows a comparison of gross primary productivity with estimates based on the FLUXCOM data set (Jung et al., 2017). Although in general the spatial patterns are similar, LPJ-GUESS predicts lower productivity in the wet tropics and higher productivity in midlatitudes. These mismatches largely compensate for each other, resulting in similar estimates for global total GPP $\left(125.1 \pm 6.9 \mathrm{Pg} \mathrm{C} \mathrm{yr}^{-1}\right.$ (mean $\pm \mathrm{SD}$ ) for FLUXCOM versus

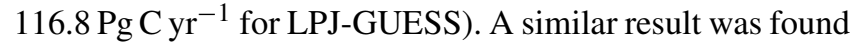
by Piao et al. (2013) for the C-only version of LPJ-GUESS.
The predicted mineral $\mathrm{N}$ leaching rates shows good agreement with estimates of the IMAGE model (Beusen et al., 2016; Fig. 9). The zonal mean by LPJ-GUESS shows a pronounced peak near the Equator, which is not mirrored by $\mathrm{N}$ leaching from IMAGE results. This is likely explained by the high $\mathrm{N}$ deposition rates in Indonesia (Sect. 3.1.1), which are not present in the $\mathrm{N}$ deposition map used as input for IMAGE (based on Dentener et al., 2006). Global total N leaching from natural lands (adjusted for changes in natural land cover) at the end of the century by the two models compares similarly well, as shown in Fig. S15b. However, before 1990 LPJ-GUESS shows substantially lower global rates. Again, this is likely explained by differences in $\mathrm{N}$ deposition, which are higher for the Beusen et al. study, before 1990 (Fig. S15a). Interestingly, the estimate of Beusen et al. (2016) is roughly constant throughout the 20th century (Fig. S15b), which is explained by a reduction of natural land cover, approximately balancing increases in $\mathrm{N}$ deposition per unit area of natural land. LPJ-GUESS predicts similarly roughly constant $\mathrm{N}$ leaching from natural lands before the 1970 s, but increasing rates after that. A likely explanation for this difference between the two models is that LPJGUESS accounts for the effect of increasing temperature on $\mathrm{N}$ mineralization while the IMAGE estimate does not.

Figure 10 compares the fraction of $\mathrm{N}$ lost by denitrification relative to total $\mathrm{N}$ loss $\left(f_{\text {denit }}\right)$ predicted by LPJ-GUESS to the two observation-based estimates of Wang et al. (2017) and Goll et al. (2017). Comparison of the maps reveals notable disagreement with regard to the spatial patterns of $f_{\text {denit }}$, also for the two observation-based data sets. However, all three estimates agree with respect to a tendency towards higher contribution of denitrification in dry regions (e.g. central North America) and lower values in the wet tropics and regions with high $\mathrm{N}$ deposition. LPJ-GUESS does appear to underestimate the importance of denitrification for the wet tropics, however, and overestimate it for northern latitudes in North America and Eurasia. 


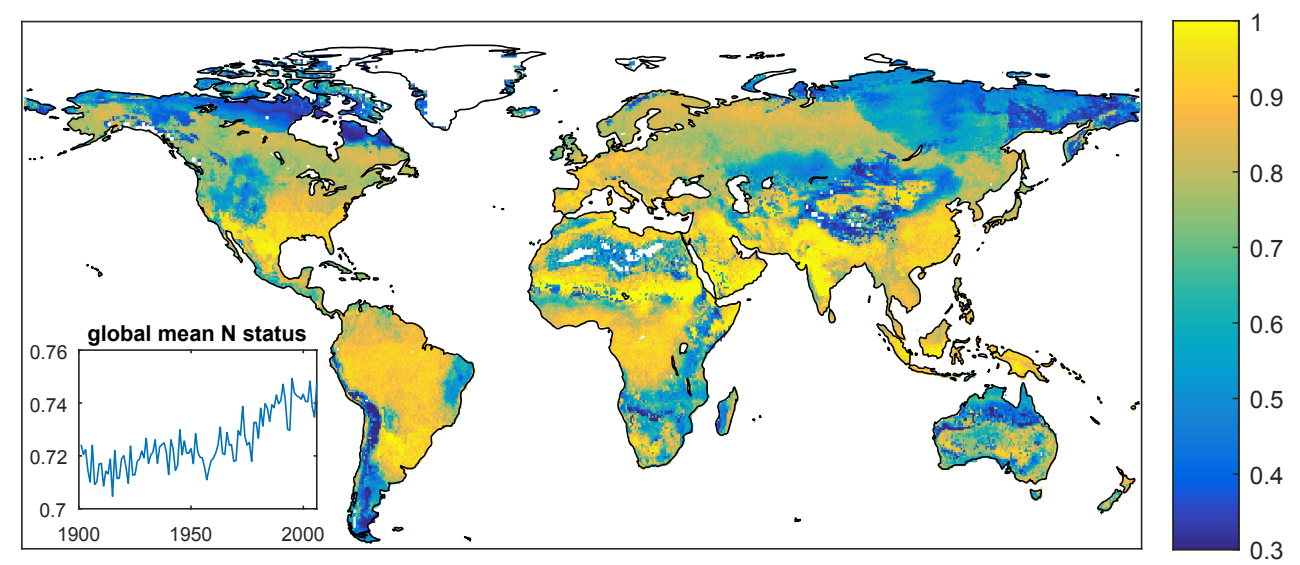

Figure 5. Ecosystem $\mathrm{N}$ status for the true historical simulation $\left(+\mathrm{Ndep}+\mathrm{clim}+\mathrm{CO}_{2}\right)$ averaged over the period 1997-2006. Lower values indicate stronger $\mathrm{N}$ limitation (see main text). The inset shows global mean $\mathrm{N}$ status over time during the simulation period.
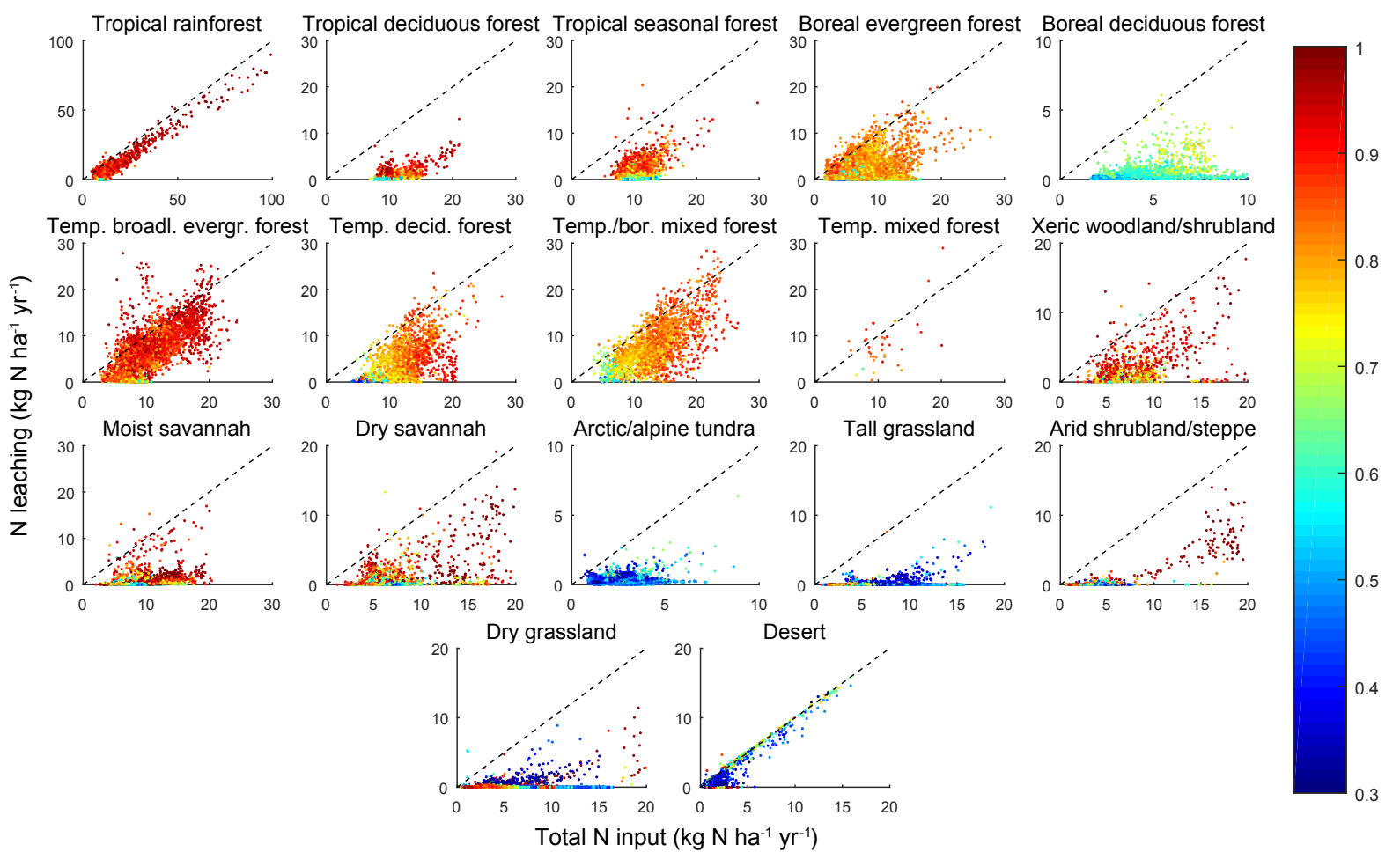

Figure 6. Mineral $\mathrm{N}$ leaching versus total $\mathrm{N}$ input (deposition $+\mathrm{BNF})$ for the true historical simulation $\left(+\mathrm{Ndep}+\mathrm{clim}+\mathrm{CO}_{2}\right)$ averaged over the period 1997-2006. Each point represents one grid cell. Colours indicate the mean N status. Dashed lines indicate the $1: 1$ relationship.

\subsection{Factorial experiment}

\subsubsection{Changes in drivers during the simulation period}

Global $\mathrm{N}$ deposition, climate, and atmospheric $\mathrm{CO}_{2}$ all changed substantially during the 20th century (Fig. S1). Global total $\mathrm{N}$ deposition changed from $18.5 \mathrm{Tg} \mathrm{N} \mathrm{yr}^{-1}$ in $1850-1860$ to more than $60 \mathrm{Tg} \mathrm{N} \mathrm{yr}^{-1}$ in $2000-2010$, corresponding to a global mean $\mathrm{N}$ deposition of $1.4{\mathrm{~kg} \mathrm{~N} \text { ha } \mathrm{yr}^{-1}}^{-1}$ and $4.4 \mathrm{~kg} \mathrm{Nha}^{-1} \mathrm{yr}^{-1}$, respectively. Mean global land sur- face temperature rose with more than $1{ }^{\circ} \mathrm{C}$ (Fig. S1b) with strongest changes in North America and Asia (Fig. S2). Global mean precipitation (Fig. S1c) does not show a strong trend, but regionally strong increases and decreases occurred (Fig. S3). Atmospheric $\mathrm{CO}_{2}$ concentration rose from 296 to 381 ppmv (Fig. S1d). 


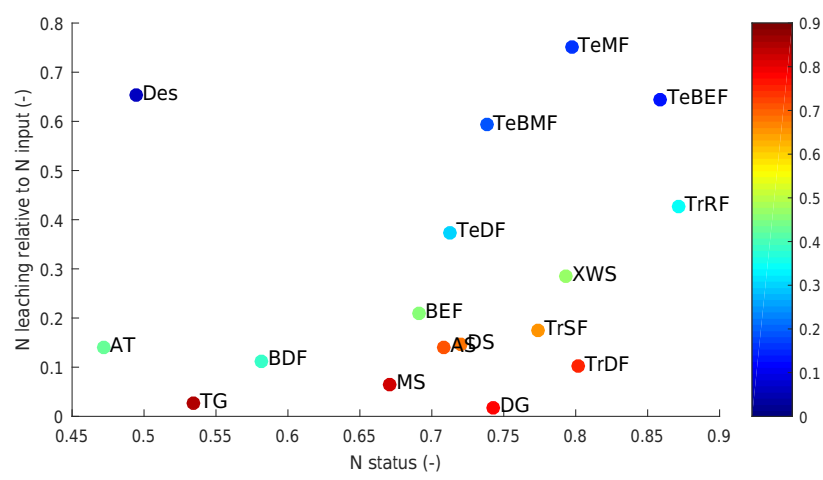

Figure 7. $\mathrm{N}$ leaching relative to total $\mathrm{N}$ input versus $\mathrm{N}$ status for the 17 biomes for the true historical simulation $\left(+\mathrm{Ndep}+\mathrm{clim}+\mathrm{CO}_{2}\right)$. Colours indicate the mean fraction of $\mathrm{N}$ lost by fire. TrRF: tropical rainforest; TrDF: tropical deciduous forest; TrSF: tropical seasonal forest; BEF: boreal evergreen forest/woodland; BDF: boreal deciduous forest/woodland; TeBEF: temperate broadleaved evergreen forest; TeDF: temperate deciduous forest; TeBMF: temperate/boreal mixed forest; TeMF: temperate mixed forest; XWS: xeric woodland/shrubland; MS: moist savannah; DS: dry savannah; AT: Arctic/alpine tundra; TG: tall grassland; AS: arid shrubland/steppe; DG: dry grassland; Des: desert.

\subsubsection{Effects on $\mathrm{N}$ leaching}

Figure 11 depicts the $\mathrm{N}$ leaching difference relative to control for the single-factor simulations. $\mathrm{N}$ leaching for two-factor simulations is shown in Fig. S17 (see also Fig. S16). For the simulation with true $\mathrm{N}$ deposition (Fig. 11a) $\mathrm{N}$ leaching response generally follows the change in $\mathrm{N}$ deposition, showing higher rates in most places except in Florida, USA, where $\mathrm{N}$ deposition showed a historical decrease in the forcing data (see Sect. 3.1.1). Climate change on the other hand has varying effects (Fig. 11b). In regions with high organic carbon storage (Russia, Canada; Fig. S13), or high N availability (Europe) the response of $\mathrm{N}$ leaching tends to be positive, due to higher $\mathrm{N}$ release by mineralization. Several regions also show decreased leaching rates such as northern India and eastern Australia, which is mainly related to a reduction in precipitation. The effect of $\mathrm{CO}_{2}$ increase (Fig. 11c) is generally negative, with strongest reductions in regions with high productivity, such as the tropics. From the three single-factor runs it is apparent that different drivers dominate in different regions for true historical simulation (Fig. 11d), e.g. rising $\mathrm{N}$ deposition in Europe and eastern Canada/USA, $\mathrm{CO}_{2}$ increase in the western Amazon, and climate (precipitation) change in northern India.

Figure 12 shows the global total $\mathrm{N}$ leaching for the eight simulations, assuming a world with potential natural vegetation only. The strongest single driver at the global scale is $\mathrm{N}$ deposition change, which by itself causes an increase of $\mathrm{N}$ leaching by $87 \%$. The overall effect of true climate is positive ( $31 \%$ increase), indicating that the increased $\mathrm{N}$ mineralization outweighs possible uptake stimulation due to higher productivity. This is explained by the fact that the effects of climate on global GPP are relatively small and mostly negative (Figs. S18, S19). In contrast, the $\mathrm{CO}_{2}$ effect on global GPP is strong, resulting in a pronounced negative effect on $\mathrm{N}$ leaching at the global scale $(-33 \%)$. Note that the opposing effects of rising $\mathrm{CO}_{2}$ and climate on $\mathrm{N}$ leaching roughly balance each other, particularly in the first half of the 20th century. Strong synergies between the drivers in relation to $\mathrm{N}$ leaching are not apparent from these results.

\section{Discussion}

\subsection{Controls on $\mathrm{N}$ leaching}

\subsubsection{N input}

Figure 6 shows that there are large differences between biomes with regard to the relationship between $\mathrm{N}$ input (deposition $+\mathrm{BNF}$ ) and leaching. These differences are mainly related to $\mathrm{N}$ status: strongly $\mathrm{N}$-limited biomes have a lower slope, meaning that relatively less $\mathrm{N}$ will be leached out. Although very low $\mathrm{N}$ status is limited to a few biomes, in most grid cells N limitation is relevant to some extent; only $\sim 8 \%$ of the grid cells have an $\mathrm{N}$ status of 0.95 or higher. However, ecosystems do not need to be fully $\mathrm{N}$ saturated before significant leaching is simulated. For many biomes, relative $\mathrm{N}$ loss by leaching starts to increase rapidly at around $\mathrm{N}$ status values of 0.6-0.7 (Fig. S7) if water fluxes are high enough. Furthermore, increases in $\mathrm{N}$ deposition occur mostly in regions that historically already had high deposition rates (Wårlind et al., 2014). Hence, at the global scale the increase in $\mathrm{N}$ deposition results in a strong increase in $\mathrm{N}$ leaching.

Several studies have reported an apparent threshold at 5$10 \mathrm{~kg} \mathrm{~N} \mathrm{ha}^{-1} \mathrm{yr}^{-1}$ in the relationship between $\mathrm{N}$ leaching and $\mathrm{N}$ deposition or throughfall in temperate forests. Below this deposition rate, $\mathrm{N}$ leaching is constant at negligible levels, while above it leaching increases linearly with in deposition, although with high variability (Butterbach-Bahl et al., 2011; Dise et al., 2009). Approximately the same threshold was found for $\mathrm{NO}_{3}^{-}$concentration in lakes and streams by Aber et al. (2003). Furthermore, a recent study on the effect of $\mathrm{N} \mathrm{de}-$ position on vegetation productivity concluded that photosynthetic capacity of forests reaches a plateau at approximately $8 \mathrm{~kg} \mathrm{Nha}^{-1} \mathrm{yr}^{-1}$ deposition (Fleischer et al., 2013). In the LPJ-GUESS predictions, a similar non-linear response is observed for the Arctic/alpine tundra and arid shrubland/steppe biomes (Fig. 6). For temperate forests, however, this behaviour is not apparent. Since the high within-biome variability may obscure the relationship, we plotted $\mathrm{N}$ deposition versus $\mathrm{N}$ leaching for the grid cells in Europe with temperate deciduous forest together with data from Level II sites of UN-ECE/EC Intensive Monitoring Programme (Fig. S20; de Vries et al., 2003; Dise et al., 2009). This does not change the essential behaviour: there is in general no $\mathrm{N}$ input rate below which $\mathrm{N}$ leaching is negligible for all cells. However, 
(a) LPJ-GUESS

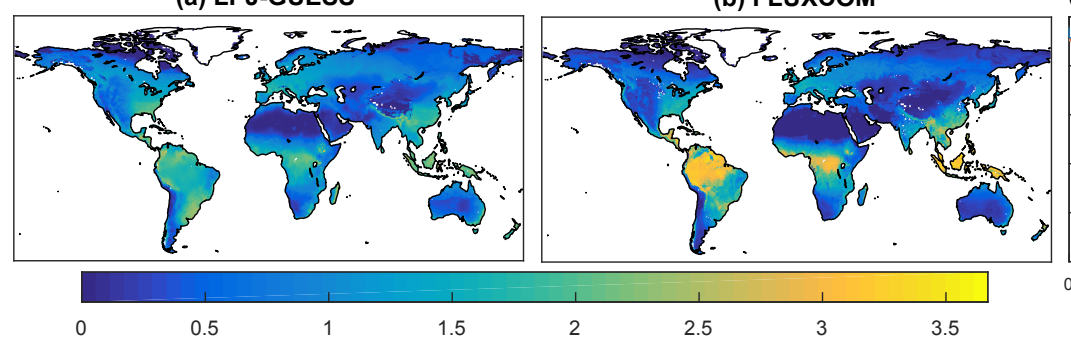

(c) Zonal mean

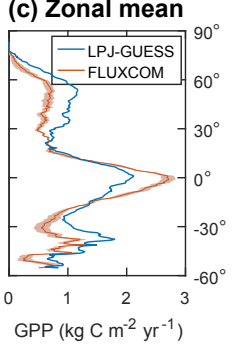

Figure 8. Mean gross primary productivity (GPP) for 1997-2006. (a) LPJ-GUESS GPP for the true historical simulation (+Ndep +clim $+\mathrm{CO}_{2}$ ). (b) FLUXCOM GPP (Jung et al., 2017), mean over six approaches. (c) Latitudinal averages. The shaded area for FLUXCOM indicates the $95 \%$ confidence range over the six approaches.

(a) LPJ-GUESS

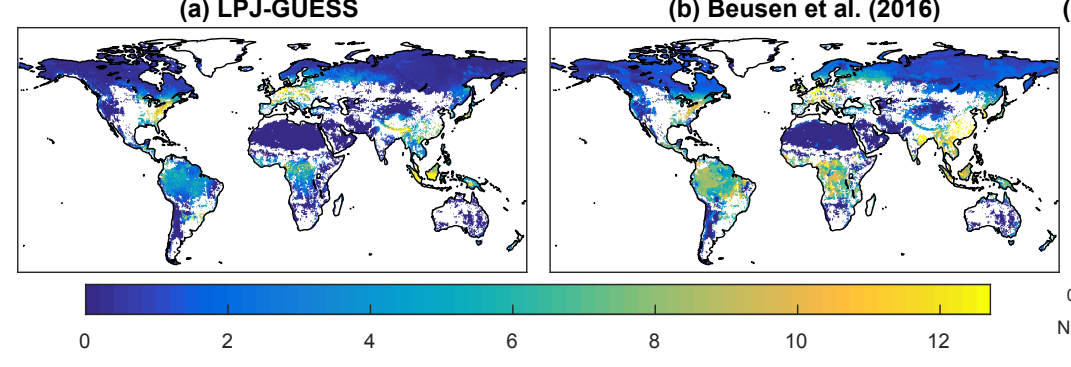

(c) Zonal means

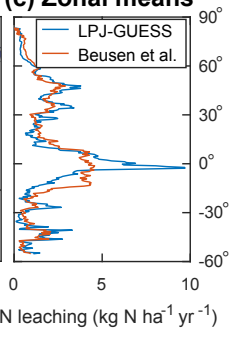

Figure 9. Mean mineral N leaching rate for 1999-2000 compared to estimates of Beusen et al. (2016). (a) Prediction by LPJ-GUESS for the true historical simulation $\left(+\mathrm{Ndep}+\mathrm{clim}+\mathrm{CO}_{2}\right)$. (b) Estimate of Beusen et al. for natural ecosystems only. (c) Latitudinal averages. The many missing values in the maps are caused by mask for natural land cover of Beusen et al. (2016) which was applied to both data sets (see Sect. 2.4).

the minimum $\mathrm{N}$ leaching (bottom of the cloud) shows an apparent threshold between 10 and $15 \mathrm{~kg} \mathrm{Nha}^{-1} \mathrm{yr}^{-1}$. Below this rate cells with negligible leaching occur, while above it virtually all cells show significant leaching.

Globally, biological $\mathrm{N}$ fixation rate (BNF) is predicted to be 18 and $32 \mathrm{Tg} \mathrm{Nyr}^{-1}$ with and without correction for non-natural land, respectively. Considerable uncertainty exists regarding true rates of BNF in natural ecosystems. The LPJ-GUESS prediction is substantially lower than estimates by Cleveland et al. (1999), which lie in the range of 100$290 \mathrm{Tg} \mathrm{N} \mathrm{yr}^{-1}$. However, recent studies suggest that this may have been an overestimation (Sullivan et al., 2014; Vitousek et al., 2013). Nevertheless, also compared to these new estimates, our global BNF rate is relatively low. This may be relevant for the tropics, where BNF provides the dominant source of $\mathrm{N}$ input for ecosystems.

\subsubsection{Climate}

Predicted $\mathrm{N}$ leaching response to climate is complicated by several issues. First, temperature and precipitation change simultaneously, since for consistency we chose to treat climate as a single factor in the experiment. Furthermore, while temperature change is globally relatively uniform and mostly positive (Fig. S2), precipitation is spatially highly variable, showing both increases and decreases over the 20th century
(Fig. S3). In many regions, the distribution of precipitation over rain days has changed as well (not shown), influencing the intensity of precipitation and thereby percolation fluxes.

Second, both temperature and precipitation affect various ecosystem processes that influence $\mathrm{N}$ leaching in opposing directions. Temperature influences both $\mathrm{N}$ mineralization and vegetation productivity, while precipitation stimulates both soil water fluxes and $\mathrm{N}$ input by $\mathrm{BNF}$, which is linked to evapotranspiration in the model. Both variables influence fire probability, which is regionally very relevant.

Globally, climate change has a positive effect on $\mathrm{N}$ leaching (Fig. 12), mainly due to an increase in net $\mathrm{N}$ mineralization caused by warming (Fig. S22), and a small and mostly negative effect on productivity (Fig. S19). Particularly in regions with high soil organic carbon storage and regions that are $\mathrm{N}$ rich (western Europe; Russia; Canada) climate change has a strong positive effect on predicted $\mathrm{N}$ leaching. Negative $\mathrm{N}$ leaching response occurs in regions with stimulated productivity, or reduced precipitation in combination with high $\mathrm{N}$ deposition (northern India). Climate change also stimulates fire occurrence.

Similar to the LPJ-GUESS results, findings of observational studies on the effect of temperature on $\mathrm{N}$ leaching vary, depending on site conditions. Soil warming experiments generally show an increase of vegetation productivity, which is usually attributed to higher $\mathrm{N}$ availability caused by stim- 
(a) LPJ-GUESS

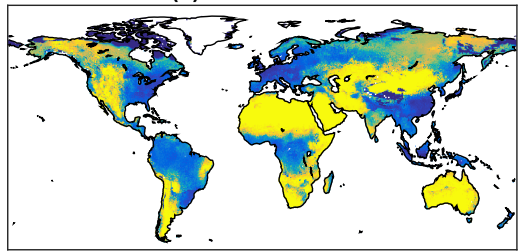

(c) Goll et al. (2017)

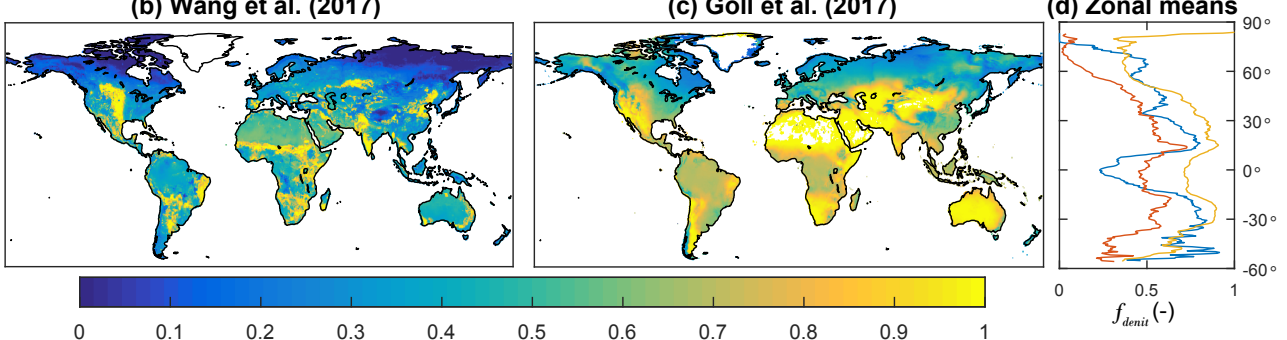

Figure 10. Relative contribution of denitrification to total soil N loss (excluding fire). (a) Prediction by LPJ-GUESS for the true historical simulation ( $+\mathrm{Ndep}+\mathrm{clim}+\mathrm{CO}_{2}$ ), 1997-2006. (b) Estimate by Wang et al. (2017). (c) Estimate by Goll et al. (2017). (d) Latitudinal averages.

(a) True $\mathrm{N}$ deposition, constant climate, constant $\mathrm{CO}_{2}$

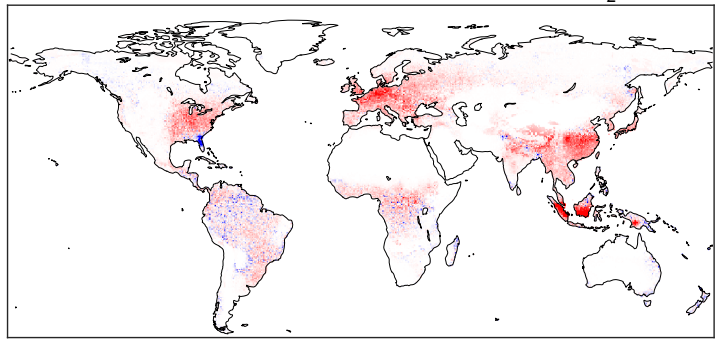

(c) Constant $\mathrm{N}$ deposition, constant climate, true $\mathrm{CO}_{2}$

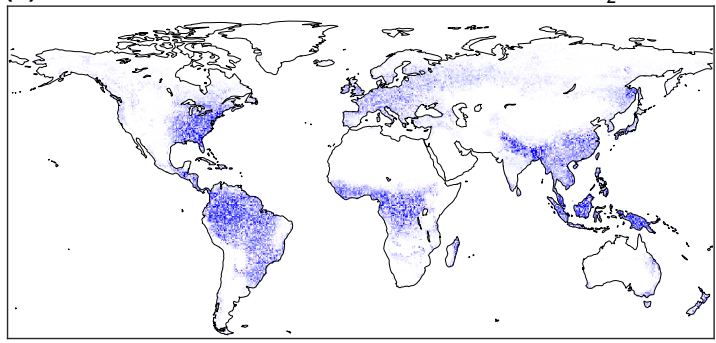

(b) Constant $\mathrm{N}$ depositon, true climate, constant $\mathrm{CO}_{2}$

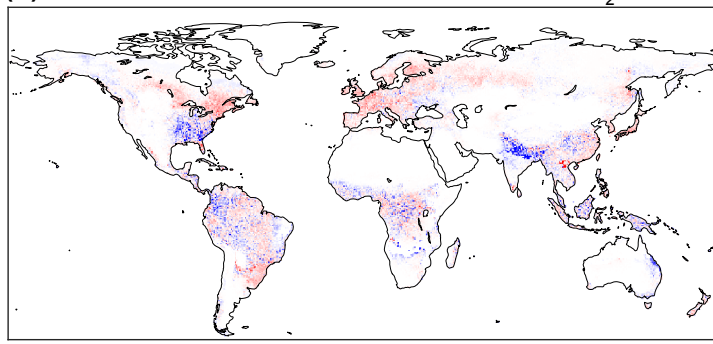

(d) True $\mathrm{N}$ deposition, true climate, true $\mathrm{CO}_{2}$

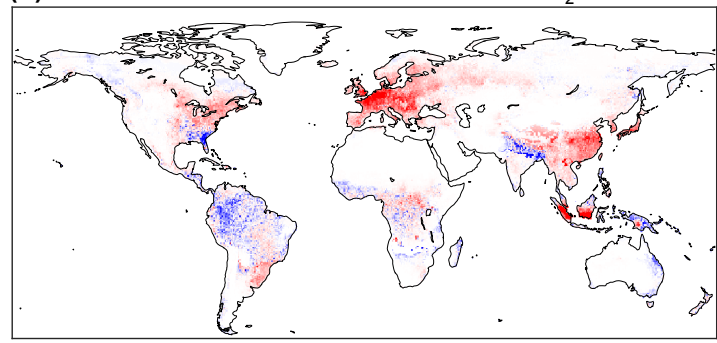

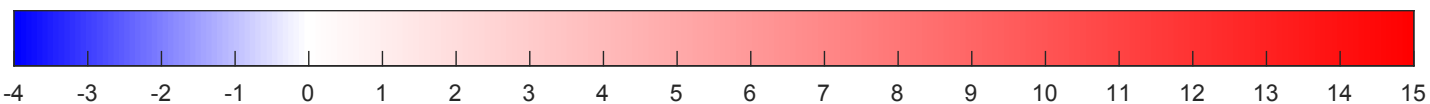

Figure 11. Mineral $\mathrm{N}$ leaching difference $\left(\mathrm{kg} \mathrm{Nha}^{-1} \mathrm{yr}^{-1}\right)$ relative to the control simulation $\left(-\mathrm{Ndep}-\mathrm{clim}-\mathrm{CO}_{2}\right)$ for the single-factor runs and the true historical simulation. For readability, the colour axis has been cut off at the 1 and $99 \%$ quantile over all graphs.

ulated mineralization (Melillo et al., 2011; Rustad et al., 2001). Studies that report leaching fluxes support the LPJGUESS results in that N-rich sites usually show a clear increase in N leaching (Joslin and Wolfe, 1993; Lükewille and Wright, 1997; Schmidt et al., 2004), while N-poor sites have a less strong response (Schmidt et al., 2004). It should be noted, however, that soil warming experiments may not be fully compatible with our results since they only account for the effect of increased $\mathrm{N}$ availability on vegetation productivity but not direct effects of increased temperature on plants.

Global long-term trends in $\mathrm{N}$ leaching do not appear to be related to precipitation in our study. At the regional scale, however, changes in precipitation can be quite important for $\mathrm{N}$ leaching, as shown by the factorial experiment 


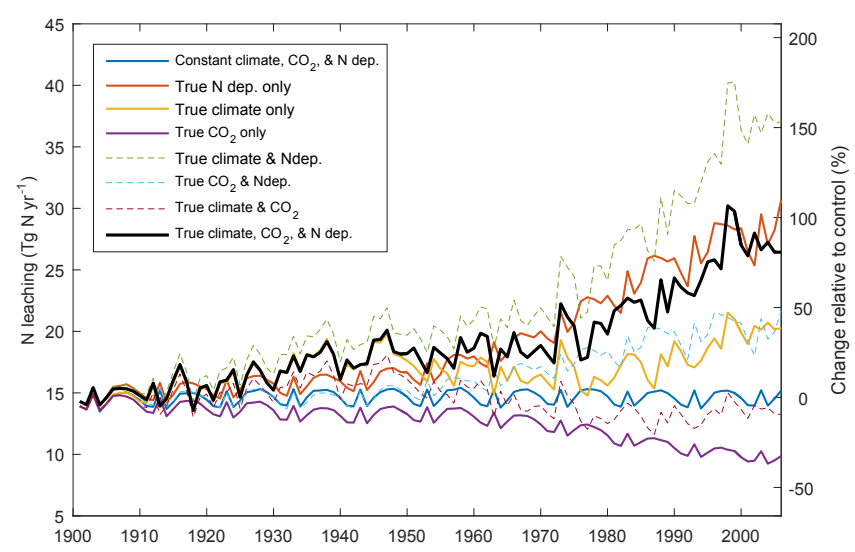

Figure 12. Global total $\mathrm{N}$ leaching for the eight simulations, for a world with potential natural vegetation only. The right-hand axis depicts change relative to the mean rate for the control simulation $\left(-\mathrm{Ndep}-\mathrm{clim}-\mathrm{CO}_{2}\right)$.

(Sect. 3.2.2). Furthermore, spatial patterns of $\mathrm{N}$ leaching are strongly linked to soil water fluxes, which relate directly to precipitation, as illustrated by the strong relationship between runoff and $\mathrm{N}$ leaching on the log-log scale (Fig. S21). This relationship compares well with findings of Lewis et al. (1999).

\subsubsection{Atmospheric $\mathrm{CO}_{2}$ concentration}

LPJ-GUESS predicts a considerable negative response of $\mathrm{N}$ leaching to changes in atmospheric $\mathrm{CO}_{2}$ concentration (Figs. 11c and 12). Strong reductions occur in regions which have high $\mathrm{N}$ availability, either due to $\mathrm{N}$ deposition (temperate biomes) or $\mathrm{N}$ fixation (tropics). Furthermore, $\mathrm{CO}_{2}$ also stimulates litter production, which tends to increase fire occurrence, resulting in volatilization $\mathrm{N}$ losses, in turn leading to a compensatory reduction in leaching in semi-arid biomes. Particularly in the tropics, LPJ-GUESS predicts a strong GPP response to $\mathrm{CO}_{2}$ increase (Fig. S19). Due to the lack of $\mathrm{CO}_{2}$ enrichment experiments in the tropics, little is known about the $\mathrm{CO}_{2}$ response of tropical forests (Hickler et al., 2008); hence it is unclear to what is extent this behaviour is realistic. It is likely that in reality phosphorus availability limits GPP response (Wang et al., 2010), which would presumably reduce the negative effects on $\mathrm{N}$ leaching.

Although there is a large body of literature on the effects of $\mathrm{CO}_{2}$ enrichment on ecosystems, few studies report $\mathrm{N}$ leaching. Several studies found reductions in $\mathrm{N}$ leaching under elevated $\mathrm{CO}_{2}$ (Hagedorn et al., 2000; Hungate et al., 1999; Johnson et al., 2004) but the absence of response has been reported as well (Larsen et al., 2011). In addition to enhancing plant productivity, elevated $\mathrm{CO}_{2}$ tends to increase water use efficiency (Dekker et al., 2016), resulting in a reduction in transpiration. This stimulates runoff and water leaching (Betts et al., 2007), which could be expected to affect $\mathrm{N}$ leaching.

\subsubsection{Fire}

LPJ-GUESS predicts that fire plays a considerable role in the $\mathrm{N}$ budget of natural ecosystems (Figs. 2, 3; S10). Globally, fires account for $33 \%$ of predicted total $\mathrm{N}$ loss in the period 1997-2006, approximately the same as the contribution of $\mathrm{N}$ leaching. Ecosystems with frequent fires are more $\mathrm{N}$ limited and leach less $\mathrm{N}$ in the model simulations. This agrees with field studies that have found that fires lead to decreased $\mathrm{N}$ leaching on longer timescales ( $>3$ years; Johnson et al., 2007). Prescribed fires have been proposed as a measure to improve surface water quality (Fenn et al., 1998; Johnson et al., 2008). On shorter timescales, however, fire may enhance leaching due to mineralization of fire-induced litter fall (Alexis et al., 2007; Johnson et al., 2008). Furthermore, at burned sites original vegetation is often replaced by $\mathrm{N}$-fixing plants, which quickly replenish lost $\mathrm{N}$ (Johnson et al., 2008). Neither of these processes is represented in LPJGUESS.

If we adjust the LPJ-GUESS prediction of global $\mathrm{N}$ fire loss for the fraction of non-natural land we find an estimate of $16.7 \mathrm{Tg} \mathrm{Nyr}^{-1}$. This compares well with observationbased estimates. For example, according to the Global Fire Emissions Database (GFED4; van der Werf et al., 2010), 16.4 $\mathrm{Tg} \mathrm{N} \mathrm{yr}^{-1}$ was emitted from natural fires globally $\left(\mathrm{N}_{2} \mathrm{O}+\mathrm{NH}_{3}+\mathrm{NO}_{x}\right)$ in 1997-2006. Schultz et al. (2008) reported a higher value for the 1990s: $24 \mathrm{Tg} \mathrm{N} \mathrm{yr}^{-1}\left(\mathrm{NH}_{3}+\right.$ $\mathrm{NO}_{x}$ ). Although uncertainty regarding $\mathrm{N}$ losses by fire is large (Gruber and Galloway, 2008), the general agreement with observations strengthens our finding of the important role of fire in the terrestrial $\mathrm{N}$ budget. Specifically for savannah ecosystems, the influence of fire on $\mathrm{N}$ dynamics is further supported by field and remote sensing studies (Veldhuis et al., 2016; Chen et al., 2010).

It should be noted that part of the emitted $\mathrm{N}$ from fire is quickly returned to the land surface by atmospheric deposition. This is not accounted for in our study, since we prescribed $\mathrm{N}$ deposition, based on the ACCMIP data set of Lamarque et al. (2013), which is derived from simulations with an ensemble of atmospheric chemistry models. The $\mathrm{N}$ emission sources used to drive these models include natural fires (Lamarque et al., 2010). However, while global total $\mathrm{N}$ emission by fire in the ACCMIP forcing (13.3 $\mathrm{Tg} \mathrm{N} \mathrm{yr}^{-1}$ ) is comparable to the estimate of LPJ-GUESS, the spatial patterns of these emissions (Fig. S11) differ substantially (Fig. S10). A more detailed modelling study that accounts for local recycling of $\mathrm{N}$ emitted by fire is needed in order to draw stronger conclusions regarding the role of fires.

\subsection{Ecosystem $\mathrm{N}$ status}

We have used the $\mathrm{N}$ limitation factor, which reflects the reduction in photosynthetic capacity due to $\mathrm{N}$ limitation, as a proxy for $\mathrm{N}$ status (Fig. 5). While this quantity is in general correlated to $\mathrm{N}$ input, its spatial variability appears to 
be more strongly related to ecosystem type (Fig. S8). The savannah, grassland, boreal forest, and tundra biomes show strong limitation, while for example tropical rainforests are generally closer to saturation. This agrees well with observational findings on the prevalence of $\mathrm{N}$ limitation in natural ecosystems (Vitousek and Howarth, 1991). Apart from differences in climate zone, the relationship between biome and $\mathrm{N}$ status is the result of the interaction of several PFTspecific interactions. Grass PFTs have higher productivity, resulting in a higher $\mathrm{N}$ demand and will thus more quickly experience $\mathrm{N}$ limitation. In LPJ-GUESS tundra vegetation is represented by $\mathrm{C}_{3}$ grass, which explains the strong $\mathrm{N}$ limitation for this biome. Ecosystems dominated by grass PFTs also experience more fire, which exacerbates $\mathrm{N}$ limitation in semi-arid regions. Phenology plays a role as well - regions with a short growing season due to seasonally low temperatures or drought are less efficient at retaining $\mathrm{N}$.

For similar reasons, the relationship between $\mathrm{N}$ status and $\mathrm{N}$ leaching is also confounded. Although in general regions with high $\mathrm{N}$ status tend to lose more $\mathrm{N}$ by leaching according to our simulations (Fig. S7), variability is large, due to the interplay of natural and ecological processes. For example, several arid regions (e.g. Chinese deserts) have generally high $\mathrm{N}$ status but leaching rates are quite low due to low water fluxes. On the other hand, in N-limited ecosystems significant leaching can still occur (Fig. 6), demonstrating that there are limits to the efficiency of plants to retain $\mathrm{N}$. To some extent these results contradict the conceptual model of N saturation proposed by Aber et al. $(1998,1989)$ which states that $\mathrm{N}$ leaching occurs at significant rates only when an ecosystem is fully $\mathrm{N}$ saturated. This view has previously been criticized by Lovett and Goodale (2011), who pointed to studies that found that $\mathrm{N}$-limited ecosystems can in fact leach considerable amounts of $\mathrm{N}$.

Thus, $\mathrm{N}$ limitation of vegetation as a proxy for $\mathrm{N}$ status is of limited value for predicting $\mathrm{N}$ leaching in a global setting. Conversely, the ratio of $\mathrm{N}$ leaching to $\mathrm{N}$ input may be a useful complementary indicator for $\mathrm{N}$ status. Ignoring high-latitude regions, this quantity is relatively high in regions with high $\mathrm{N}$ inputs (e.g. western Europe, eastern USA, South-East Asia, and the tropics; Fig. 4b), which agrees with observational findings that the proportion of $\mathrm{N}$ lost by leaching increases with $\mathrm{N}$ deposition (Aber et al., 2003; Fenn et al., 1998).

\subsection{Comparison of $\mathrm{N}$ cycling predictions with other large-scale studies}

As discussed in Sect. 3.1.3, there is good spatial agreement with $\mathrm{N}$ leaching rates of Beusen et al. (2016) despite the differences between the models. This resemblance likely results at least partially from similarities in the $\mathrm{N}$ deposition maps used as input (notwithstanding Indonesia; see Sect. 3.1.1). Although different data sources were used (Lamarque et al., 2013 for our study; Dentener et al., 2006 for Beusen et al., 2016), there is considerable agreement between the two.
Conversely, earlier in the 20th century $\mathrm{N}$ deposition input matches less well and, consequently, so does the predicted $\mathrm{N}$ leaching (Fig. S15b). Nevertheless, given the high uncertainty associated with these estimates, the good agreement for contemporary conditions is encouraging.

As discussed in Sect. 2.1.2, the representation of denitrification in the version of LPJ-GUESS used in this study is based on a simple empirical relationship ( $1 \%$ of daily $\mathrm{N}$ mineralization). While $\mathrm{N}$ loss due to denitrification is highly relevant for $\mathrm{N}$ leaching, accurate estimation of its contribution to the total $\mathrm{N}$ budget at large spatial scale remains a considerable challenge, with observation-based approaches, as well as mechanistic models. This is demonstrated by the disagreement between different estimates of $f_{\text {denit }}$, depicted in Fig. 10. The zonal means show somewhat better agreement, but in general the difference between the LPJ-GUESS predictions and two other data sets is smaller than the difference among the observation-based estimates themselves. Nevertheless, certain observed patterns are reproduced by LPJGUESS, such as the relatively large contribution of denitrification in arid regions, caused by low percolation rates, and a tendency towards lower contribution in regions with high $\mathrm{N}$ deposition. An exception are the wet tropics, for which LPJ-GUESS predicts a lower contribution of denitrification compared to both observation-based data sets. A possible explanation for this mismatch is the fact that in wet regions high moisture availability creates conditions favourable for denitrification. In LPJ-GUESS, $\mathrm{N}$ leaching rates are more strongly linked to moisture availability (via drainage fluxes) than denitrification rates, resulting in a comparatively large predicted contribution of leaching.

After correction for non-natural land cover, based on the land-use data set of Hurtt et al. (2011; see Sect. 2.3), we estimate a global $\mathrm{N}$ leaching rate of $18.5 \mathrm{Tg} \mathrm{N} \mathrm{yr}^{-1}$ from natural ecosystems for 1997-2006. Although several studies have quantified terrestrial $\mathrm{N}$ export, most of these do not distinguish contributions from different land cover types. The studies that did report the contribution of natural ecosystems found rates of a magnitude comparable to our estimate. For example, Zaehle et al. (2010) found a substantially higher value of $27 \mathrm{Tg} \mathrm{N} \mathrm{yr}^{-1}$ for the 1990s based on a simulation with the OCN land surface model. The difference with our study is at least partially explained by their higher estimate of biological $\mathrm{N}$ fixation $\left(107.8 \mathrm{Tg} \mathrm{N} \mathrm{yr}^{-1}\right)$. Recently, Nevison et al. (2016) reported N export (leaching + surface runoff) for 1995-2005, from a simulation with the Community Land Model with natural vegetation only. As a rough correction for non-natural land, we may multiply their estimate $\left(10.6 \mathrm{Tg} \mathrm{N} \mathrm{yr}^{-1}\right)$ by 0.64 , the ratio of our rate and the predicted $\mathrm{N}$ leaching for a completely natural world (28.6 $\mathrm{Tg} \mathrm{N} \mathrm{yr}^{-1}$ ). This yields a value of $6.8 \mathrm{Tg} \mathrm{N} \mathrm{yr}^{-1}$, which is considerably lower than other published rates, including ours. The authors acknowledged that this is likely an underestimation caused by too high denitrification rates. 


\subsection{Model limitations}

The LPJ-GUESS model is part of the state of the art of global ecosystem modelling and compares favourably with other models in model-data comparison studies (Zaehle et al., 2014). Furthermore, although the latitudinal pattern of GPP shows some mismatch with data-driven estimates (Sect. 3.1.3), overall, agreement is sufficient for the purpose of this study. Nevertheless, uncertainties in modelling $\mathrm{N}$ cycling at the global scale are in general high. Competing model representations yield divergent results (Zaehle and Dalmonech, 2011), and available observations are currently not sufficient to identify best parametrizations. We will discuss several specific model limitations of LPJ-GUESS (also present in other models) that are particularly relevant for $\mathrm{N}$ leaching.

An important source of uncertainty stems from the representation of biological $\mathrm{N}$ fixation. As mentioned previously, BNF predicted by LPJ-GUESS is 3- to 9-fold lower than observation-based estimates (Cleveland et al., 1999), which may be expected to cause underestimation of leaching. Furthermore, in LPJ-GUESS BNF occurs passively without an explicit link to vegetation productivity or ecosystem $\mathrm{N}$ status. In reality plants are believed to exert some control on BNF rates based on the balance between $\mathrm{N}$ demand and availability (Vitousek et al., 2002). Since there is a considerable energy cost involved, plants tend to down-regulate BNF under $\mathrm{N}$-rich conditions in favour of other pathways such as mycorrhizal or passive uptake (Houlton et al., 2015). Similarly, N resorption from leaves before senescence - assumed a fixed fraction of $50 \%$ in LPJ-GUESS - tends to be lower under Nrich conditions. More mechanistic descriptions of plant $\mathrm{N}$ acquisition have been proposed (Brzostek et al., 2014), which account for these feedbacks, and could potentially result in improved prediction of ecosystem $\mathrm{N}$ cycling and leaching under varying conditions.

In the current version of LPJ-GUESS all mineral nitrogen forms are lumped into a single pool. In reality, however, inorganic nitrogen in soils exists in a range of chemical forms, most importantly nitrate $\left(\mathrm{NO}_{3}^{-}\right)$and ammonium $\left(\mathrm{NH}_{4}^{+}\right)$. The behaviour of these two species in soil differs considerably (Butterbach-Bahl et al., 2011). Ammonium is much less susceptible to leaching since soils generally have a much higher capacity for retaining cations than anions. As a result, inorganic $\mathrm{N}$ losses occur mainly in the form of nitrate and its formation by nitrification is an important control for leaching losses (Zhang et al., 2016). Since plants and microbes preferentially take up ammonium over nitrate, nitrification rates are usually low in $\mathrm{N}$-limited ecosystems. Hence, it is possible that leaching losses are overestimated in N-limited ecosystems, which may explain the mismatch with observations (Fig. S20) at low N deposition rates. Transformation of ammonium to nitrate by nitrification and vice versa by denitrification are associated with gaseous losses. The rates of these processes are highly dependent on substrate concentra- tions and soil aeration status. Denitrification can be a considerable loss term in the $\mathrm{N}$ budget particularly under anaerobic conditions (Bouwman et al., 2013a). The relatively simple representation of denitrification ( $1 \%$ of gross $\mathrm{N}$ mineralization) in LPJ-GUESS roughly reproduces global spatial patterns of relative $\mathrm{N}$ loss by this process (Sects. 3.1.3 and 4.3), but it is possible that predictions of $\mathrm{N}$ leaching are overestimated leaching losses in soils with high $\mathrm{N}$ availability under wet conditions. Currently, LPJ-GUESS is being updated with an improved description of soil $\mathrm{N}$ cycling based on the approach of Xu-Ri and Prentice (2008) that accounts for different mineral $\mathrm{N}$ species and transformations between them.

Finally, LPJ-GUESS predicts that dissolved organic N (DON) leaching is generally negligible compared to the overall $\mathrm{N}$ budget (Fig. S6; globally $0.18 \%$ of total $\mathrm{N}$ loss for 1997-2006), which likely represents an underestimation. Observations based on river concentrations indicate that DON loss can be a significant component of ecosystem $\mathrm{N}$ export, particularly in N-limited regions (Perakis and Hedin, 2002). In process-based modelling studies DON leaching has been largely ignored as a significant $\mathrm{N}$ sink, which is increasingly recognized as a limitation (Nevison et al., 2016).

\section{Conclusions}

The factorial experiment with LPJ-GUESS allows us to disentangle the effects of changes in $\mathrm{N}$ deposition, climate, and atmospheric $\mathrm{CO}_{2}$ concentration on $\mathrm{N}$ leaching. From a global perspective $\mathrm{N}$ deposition is the most important control of $\mathrm{N}$ leaching in our model simulations. Rising $\mathrm{N}$ deposition during the 20th century has caused large increases in $\mathrm{N}$ leaching in many regions in the world. Rising atmospheric $\mathrm{CO}_{2}$ and climate change, of secondary - but not negligible - importance, have a negative and a positive effect on $\mathrm{N}$ leaching, respectively. Although temporal trends are clear at the global scale, there are large regional differences, even when individual drivers are considered. This variability results largely from heterogeneity of climate and $\mathrm{N}$ deposition changes and biome type, and causes complex spatial patterns when all three drivers are combined. These patterns would have been difficult to understand based on the true historical simulation alone. Ecosystem $\mathrm{N}$ status is more difficult to assess based on our results. Spatial patterns of $\mathrm{N}$ limitation on vegetation productivity are more strongly related to vegetation type than $\mathrm{N}$ input. Nevertheless, at the global scale, $\mathrm{N}$ limitation is clearly decreasing and regions with highest $\mathrm{N}$ deposition are approaching $\mathrm{N}$ saturation.

Data availability. Model output produced in this work is hosted at the Data Archiving and Networked Services (DANS) of the Netherlands Organisation for Scientific Research (NWO): https://doi.org/10.17026/dans-zrx-7xhu (Braakhekke, 2016). 


\section{The Supplement related to this article is available online at https://doi.org/10.5194/esd-8-1121-2017-supplement.}

Competing interests. The authors declare that they have no conflict of interest.

Acknowledgements. We are indebted to Mats Lindeskog, Stefan Olin, Michael Mischurow, and David Wårlind for help with setting up and running LPJ-GUESS and interpreting the results. Also, we are grateful to Martin Jung and Ulrich Weber, for the providing the FLUXCOM GPP data, and to Edith Bai, Daniel Goll, Alexander Winkler, and Bas Kempen for providing the $f_{\text {denit }}$ data sets and help with its processing. Finally, we thank the three anonymous reviewers for their helpful comments, which substantially improved the paper. This work was supported by funding from the global water cycle modelling project of Utrecht University and sponsored by NWO Physical Sciences for the use of supercomputer facilities. This study contributes to the Strategic Research Areas BECC and MERGE of the Swedish Research Council.

Edited by: Zhenghui Xie

Reviewed by: three anonymous referees

\section{References}

Aber, J., McDowell, W., Nadelhoffer, K., Magill, A., Berntson, G., Kamakea, M., McNulty, S., Currie, W., Rustad, L., and Fernandez, I.: Nitrogen saturation in temperate forest ecosystems - Hypotheses revisited, Bioscience, 48, 921-934, https://doi.org/10.2307/1313296, 1998.

Aber, J. D., Nadelhoffer, K. J., Steudler, P., and Melillo, J. M.: Nitrogen Saturation in Northern Forest Ecosystems, BioScience, 39, 378-386, https://doi.org/10.2307/1311067, 1989.

Aber, J. D., Ollinger, S. V., and Driscoll, C. T.: Modeling nitrogen saturation in forest ecosystems in response to land use and atmospheric deposition, Ecol. Model., 101, 61-78, https://doi.org/10.1016/S0304-3800(97)01953-4, 1997.

Aber, J. D., Goodale, C. L., Ollinger, S. V., Smith, M.-L., Magill, A. H., Martin, M. E., Hallett, R. A., and Stoddard, J. L.: Is Nitrogen Deposition Altering the Nitrogen Status of Northeastern Forests?, BioScience, 53, 375-389, https://doi.org/10.1641/00063568(2003)053[0375:INDATN]2.0.CO;2, 2003.

Ågren, G. I. and Bosatta, E.: Nitrogen saturation of terrestrial ecosystems, Environ. Pollut., 54, 185-197, https://doi.org/10.1016/0269-7491(88)90111-X, 1988.

Alexis, M. A., Rasse, D. P., Rumpel, C., Bardoux, G., Péchot, N., Schmalzer, P., Drake, B., and Mariotti, A.: Fire impact on C and $\mathrm{N}$ losses and charcoal production in a scrub oak ecosystem, Biogeochemistry, 82, 201-216, https://doi.org/10.1007/s10533-0069063-1, 2007

Bai, E., Houlton, B. Z., and Wang, Y. P.: Isotopic identification of nitrogen hotspots across natural terrestrial ecosystems, Biogeosciences, 9, 3287-3304, https://doi.org/10.5194/bg-9-32872012, 2012.
Beier, C., Emmett, B., Penuelas, J., Schmidt, I., Tietema, A., Estiarte, M., Gundersen, P., Llorens, L., Riisnielsen, T., and Sowerby, A.: Carbon and nitrogen cycles in European ecosystems respond differently to global warming, Sci. Total Environ., 407, 692-697, https://doi.org/10.1016/j.scitotenv.2008.10.001, 2008.

Betts, R. A., Boucher, O., Collins, M., Cox, P. M., Falloon, P. D., Gedney, N., Hemming, D. L., Huntingford, C., Jones, C. D., Sexton, D. M. H., and Webb, M. J.: Projected increase in continental runoff due to plant responses to increasing carbon dioxide, Nature, 448, 1037-1041, https://doi.org/10.1038/nature06045, 2007.

Beusen, A. H. W., Bouwman, A. F., Van Beek, L. P. H., Mogollón, J. M., and Middelburg, J. J.: Global riverine $\mathrm{N}$ and $\mathrm{P}$ transport to ocean increased during the 20th century despite increased retention along the aquatic continuum, Biogeosciences, 13, 24412451, https://doi.org/10.5194/bg-13-2441-2016, 2016.

Bouwman, A. F., Beusen, A. H. W., Griffioen, J., van Groenigen, J. W., Hefting, M. M., Oenema, O., van Puijenbroek, P. J. T. M., Seitzinger, S., Slomp, C. P., and Stehfest, E.: Global trends and uncertainties in terrestrial denitrification and $\mathrm{N}_{2} \mathrm{O}$ emissions, Philos. T. R. Soc. B, 368, 20130112, https://doi.org/10.1098/rstb.2013.0112, 2013a.

Bouwman, L., Goldewijk, K. K., van der Hoek, K. W., Beusen, A. H. W., van Vuuren, D. P., Willems, J., Rufino, M. C., and Stehfest, E.: Exploring global changes in nitrogen and phosphorus cycles in agriculture induced by livestock production over the 1900-2050 period, P. Natl. Acad. Sci., 110, 20882-20887, https://doi.org/10.1073/pnas.1012878108, 2013b.

Braakhekke, M. C.: Nitrogen leaching from natural ecosystems under global change: a modelling study, DANS, available at: https://doi.org/10.17026/dans-zrx-7xhu, 2016.

Brzostek, E. R., Fisher, J. B., and Phillips, R. P.: Modeling the carbon cost of plant nitrogen acquisition: Mycorrhizal trade-offs and multipath resistance uptake improve predictions of retranslocation: Carbon cost of mycorrhizae, J. Geophys. Res.-Biogeo., 119, 1684-1697, https://doi.org/10.1002/2014JG002660, 2014.

Butterbach-Bahl, K., Gundersen, P., Ambus, P., Augustin, J., Beier, C., Boeckx, P., Dannenmann, M., Sanchez Gimeno, B., Ibrom, A., Kiese, R., Kitzler, B., Rees, R. M., Smith, K. A., Stevens, C., Vesala, T., and Zechmeister-Boltenstern, S.: Nitrogen processes in terrestrial ecosystems, in The European nitrogen assessment: sources, effects and policy perspectives, edited by: Sutton, M. A., Howard, C. M., Erisman, J. W., Billen, G., Bleeker, A., Grennfelt, P., van Grisven, H., and Grizzetti, B., Cambridge University Press, New York, 99-125, 2011.

Chen, Y., Randerson, J. T., van der Werf, G. R., Morton, D. C., Mu, M., and Kasibhatla, P. S.: Nitrogen deposition in tropical forests from savanna and deforestation fires, Glob. Change Biol., 16, 2024-2038, https://doi.org/10.1111/j.13652486.2009.02156.x, 2010.

Cleveland, C. C., Townsend, A. R., Schimel, D. S., Fisher, H., Howarth, R. W., Hedin, L. O., Perakis, S. S., Latty, E. F., Von Fischer, J. C., Elseroad, A., and Wasson, M. F.: Global patterns of terrestrial biological nitrogen $\left(\mathrm{N}_{2}\right)$ fixation in natural ecosystems, Global Biogeochem. Cy., 13, 623-645, https://doi.org/10.1029/1999GB900014, 1999.

de Graaff, M.-A., van Groenigen, K.-J., Six, J., Hungate, B., and van Kessel, C.: Interactions between plant growth and soil 
nutrient cycling under elevated $\mathrm{CO}_{2}$ : a meta-analysis, Glob. Change Biol., 12, 2077-2091, https://doi.org/10.1111/j.13652486.2006.01240.x, 2006.

Dekker, S. C., Groenendijk, M., Booth, B. B. B., Huntingford, C., and Cox, P. M.: Spatial and temporal variations in plant water-use efficiency inferred from tree-ring, eddy covariance and atmospheric observations, Earth Syst. Dynam., 7, 525-533, https://doi.org/10.5194/esd-7-525-2016, 2016.

Dentener, F., Drevet, J., Lamarque, J. F., Bey, I., Eickhout, B., Fiore, A. M., Hauglustaine, D., Horowitz, L. W., Krol, M., Kulshrestha, U. C., Lawrence, M., Galy-Lacaux, C., Rast, S., Shindell, D., Stevenson, D., Van Noije, T., Atherton, C., Bell, N., Bergman, D., Butler, T., Cofala, J., Collins, B., Doherty, R., Ellingsen, K., Galloway, J., Gauss, M., Montanaro, V., Müller, J. F., Pitari, G., Rodriguez, J., Sanderson, M., Solmon, F., Strahan, S., Schultz, M., Sudo, K., Szopa, S., and Wild, O.: Nitrogen and sulfur deposition on regional and global scales: A multimodel evaluation, Global Biogeochem. Cy., 20, GB4003, https://doi.org/10.1029/2005GB002672, 2006.

de Vries, W., Vel, E., Reinds, G. J., Deelstra, H., Klap, J. M., Leeters, E. E. J. M., Hendriks, C. M. A., Kerkvoorden, M., Landmann, G., Herkendell, J., Haussmann, T., and Erisman, J. W.: Intensive monitoring of forest ecosystems in Europe, Forest Ecol. Manag., 174, 77-95, https://doi.org/10.1016/S03781127(02)00029-4, 2003.

Dise, N. B., Rothwell, J. J., Gauci, V., van der Salm, C., and de Vries, W.: Predicting dissolved inorganic nitrogen leaching in European forests using two independent databases, Sci. Total Environ., 407, 1798-1808, https://doi.org/10.1016/j.scitotenv.2008.11.003, 2009.

Fenn, M. E., Poth, M. A., Aber, J. D., Baron, J. S., Bormann, B. T., Johnson, D. W., Lemly, A. D., McNulty, S. G., Ryan, D. F., and Stottlemyer, R.: Nitrogen Excess in North American Ecosystems: Predisposing Factors, Ecosystem Responses, and Management Strategies, Ecol. Appl., 8, 706-733, https://doi.org/10.2307/2641261, 1998.

Finzi, A. C., Norby, R. J., Calfapietra, C., Gallet-Budynek, A., Gielen, B., Holmes, W. E., Hoosbeek, M. R., Iversen, C. M., Jackson, R. B., Kubiske, M. E., Ledford, J., Liberloo, M., Oren, R., Polle, A., Pritchard, S., Zak, D. R., Schlesinger, W. H., and Ceulemans, R.: Increases in nitrogen uptake rather than nitrogen-use efficiency support higher rates of temperate forest productivity under elevated $\mathrm{CO}_{2}$, P. Natl. Acad. Sci. USA, 104, 14014-14019, https://doi.org/10.1073/pnas.0706518104, 2007.

Fleischer, K., Rebel, K. T., van der Molen, M. K., Erisman, J. W., Wassen, M. J., van Loon, E. E., Montagnani, L., Gough, C. M., Herbst, M., Janssens, I. A., Gianelle, D., and Dolman, A. J.: The contribution of nitrogen deposition to the photosynthetic capacity of forests, Global Biogeochem. Cy., 27, 187-199, https://doi.org/10.1002/gbc.20026, 2013.

Galloway, J. N., Dentener, F. J., Capone, D. G., Boyer, E. W., Howarth, R. W., Seitzinger, S. P., Asner, G. P., Cleveland, C. C., Green, P. A., Holland, E. A., Karl, D. M., Michaels, A. F., Porter, J. H., Townsend, A. R., and Vörösmarty, C. J.: Nitrogen Cycles: Past, Present, and Future, Biogeochemistry, 70, 153-226, https://doi.org/10.1007/s10533-004-0370-0, 2004.

Gerber, S., Hedin, L. O., Oppenheimer, M., Pacala, S. W., and Shevliakova, E.: Nitrogen cycling and feedbacks in a global dynamic land model, Global Biogeochem. Cy., 24, GB1001, https://doi.org/10.1029/2008GB003336, 2010.

Gerten, D., Schaphoff, S., Haberlandt, U., Lucht, W., and Sitch, S.: Terrestrial vegetation and water balance-hydrological evaluation of a dynamic global vegetation model, J. Hydrol., 286, 249-270, https://doi.org/10.1016/j.jhydrol.2003.09.029, 2004.

Goll, D. S., Winkler, A. J., Raddatz, T., Dong, N., Prentice, I. C., Ciais, P., and Brovkin, V.: Carbon-nitrogen interactions in idealized simulations with JSBACH (version 3.10), Geosci. Model Dev., 10, 2009-2030, https://doi.org/10.5194/gmd-102009-2017, 2017.

Groenendijk, P., Renaud, L. V., and Roelsma, J.: Prediction of nitrogen and phosphorus leaching to groundwater and surface waters; process descriptions of the ANIMO 4.0 model, Alterra, Wageningen, 2005.

Gruber, N. and Galloway, J. N.: An Earth-system perspective of the global nitrogen cycle, Nature, 451, 293-296, https://doi.org/10.1038/nature06592, 2008.

Hagedorn, F., Bucher, J. B., Tarjan, D., Rusert, P., and Bucher-Wallin, I.: Responses of $\mathrm{N}$ fluxes and pools to elevated atmospheric $\mathrm{CO}_{2}$ in model forest ecosystems with acidic and calcareous soils, Plant Soil, 224, 273-286, https://doi.org/10.1023/A:1004831401190, 2000.

Haverd, V., Smith, B., Nieradzik, L. P., and Briggs, P. R.: A stand-alone tree demography and landscape structure module for Earth system models: integration with inventory data from temperate and boreal forests, Biogeosciences, 11, 4039-4055, https://doi.org/10.5194/bg-11-4039-2014, 2014.

Haxeltine, A. and Prentice, I. C.: A General Model for the LightUse Efficiency of Primary Production, Funct. Ecol., 10, 551-561, https://doi.org/10.2307/2390165, 1996.

Hickler, T., Prentice, I. C., Smith, B., Sykes, M. T., and Zaehle, S.: Implementing plant hydraulic architecture within the LPJ Dynamic Global Vegetation Model, Global Ecol. Biogeogr., 15, 567-577, https://doi.org/10.1111/j.1466-822x.2006.00254.x, 2006.

Hickler, T., Smith, B., Prentice, I. C., Mjöfors, K., Miller, P., Arneth, A., and Sykes, M. T.: $\mathrm{CO}_{2}$ fertilization in temperate FACE experiments not representative of boreal and tropical forests, Glob. Change Biol., 14, 1531-1542, https://doi.org/10.1111/j.13652486.2008.01598.x, 2008.

Houlton, B. Z., Marklein, A. R., and Bai, E.: Representation of nitrogen in climate change forecasts, Nat. Clim. Change, 5, 398401, https://doi.org/10.1038/nclimate2538, 2015.

Hungate, B. A., Dijkstra, P., Johnson, D. W., Hinkle, C. R., and Drake, B. G.: Elevated $\mathrm{CO}_{2}$ increases nitrogen fixation and decreases soil nitrogen mineralization in Florida scrub oak, Glob. Change Biol., 5, 781-789, https://doi.org/10.1046/j.13652486.1999.00275.x, 1999.

Hurtt, G. C., Chini, L. P., Frolking, S., Betts, R. A., Feddema, J., Fischer, G., Fisk, J. P., Hibbard, K., Houghton, R. A., Janetos, A., Jones, C. D., Kindermann, G., Kinoshita, T., Klein Goldewijk, K., Riahi, K., Shevliakova, E., Smith, S., Stehfest, E., Thomson, A., Thornton, P., van Vuuren, D. P., and Wang, Y. P.: Harmonization of land-use scenarios for the period 1500-2100: 600 years of global gridded annual land-use transitions, wood harvest, and resulting secondary lands, Clim. Change, 109, 117161, https://doi.org/10.1007/s10584-011-0153-2, 2011. 
Jain, A., Yang, X., Kheshgi, H., McGuire, A. D., Post, W., and Kicklighter, D.: Nitrogen attenuation of terrestrial carbon cycle response to global environmental factors, Global Biogeochem. Cy., 23, GB4028, https://doi.org/10.1029/2009GB003519, 2009.

Johnson, D., Murphy, J. D., Walker, R. F., Glass, D. W., and Miller, W. W.: Wildfire effects on forest carbon and nutrient budgets, Ecol. Eng., 31, 183-192, https://doi.org/10.1016/j.ecoleng.2007.03.003, 2007.

Johnson, D. W., Cheng, W., Joslin, J. D., Norby, R. J., Edwards, N. T., and Todd, D. E.: Effects of elevated $\mathrm{CO}_{2}$ on nutrient cycling in a sweetgum plantation, Biogeochemistry, 69, 379-403, https://doi.org/10.1023/B:BIOG.0000031054.19158.7c, 2004.

Johnson, D. W., Fenn, M. E., Miller, W. W., and Hunsaker, C. F.: Fire Effects on Carbon and Nitrogen Cycling in Forests of The Sierra Nevada, in Wildland fires and air pollution, edited by: Bytnerowicz, A., Arbaugh, M. J., Riebau, A. R., and Andersen, C., Elsevier, Amsterdam, London, 2008.

Joslin, J. D. and Wolfe, M. H.: Temperature increase accelerates nitrate release from high-elevation red spruce soils, Can. J. Forest Res., 23, 756-759, https://doi.org/10.1139/x93-099, 1993.

Jung, M., Reichstein, M., Schwalm, C. R., Huntingford, C., Sitch, S., Ahlström, A., Arneth, A., Camps-Valls, G., Ciais, P., Friedlingstein, P., Gans, F., Ichii, K., Jain, A. K., Kato, E., Papale, D., Poulter, B., Raduly, B., Rödenbeck, C., Tramontana, G., Viovy, N., Wang, Y.-P., Weber, U., Zaehle, S., and Zeng, N.: Compensatory water effects link yearly global land $\mathrm{CO}_{2}$ sink changes to temperature, Nature, 541, 516-520, https://doi.org/10.1038/nature20780, 2017.

Lamarque, J.-F., Bond, T. C., Eyring, V., Granier, C., Heil, A., Klimont, Z., Lee, D., Liousse, C., Mieville, A., Owen, B., Schultz, M. G., Shindell, D., Smith, S. J., Stehfest, E., Van Aardenne, J., Cooper, O. R., Kainuma, M., Mahowald, N., McConnell, J. R., Naik, V., Riahi, K., and van Vuuren, D. P.: Historical (1850-2000) gridded anthropogenic and biomass burning emissions of reactive gases and aerosols: methodology and application, Atmos. Chem. Phys., 10, 7017-7039, https://doi.org/10.5194/acp-10-7017-2010, 2010.

Lamarque, J.-F., Dentener, F., McConnell, J., Ro, C.-U., Shaw, M., Vet, R., Bergmann, D., Cameron-Smith, P., Dalsoren, S., Doherty, R., Faluvegi, G., Ghan, S. J., Josse, B., Lee, Y. H., MacKenzie, I. A., Plummer, D., Shindell, D. T., Skeie, R. B., Stevenson, D. S., Strode, S., Zeng, G., Curran, M., Dahl-Jensen, D., Das, S., Fritzsche, D., and Nolan, M.: Multi-model mean nitrogen and sulfur deposition from the Atmospheric Chemistry and Climate Model Intercomparison Project (ACCMIP): evaluation of historical and projected future changes, Atmos. Chem. Phys., 13, 7997-8018, https://doi.org/10.5194/acp-137997-2013, 2013.

Larsen, K. S., Andresen, L. C., Beier, C., Jonasson, S., Albert, K. R., Ambus, P., Arndal, M. F., Carter, M. S., Christensen, S., Holmstrup, M., Ibrom, A., Kongstad, J., van der Linden, L., Maraldo, K., Michelsen, A., Mikkelsen, T. N., Pilegaard, K., Priemé, A., Ro-Poulsen, H., Schmidt, I. K., Selsted, M. B., and Stevnbak, K.: Reduced N cycling in response to elevated $\mathrm{CO}_{2}$, warming, and drought in a Danish heathland: Synthesizing results of the CLIMAITE project after two years of treatments, Glob. Change Biol., 17, 1884-1899, https://doi.org/10.1111/j.13652486.2010.02351.x, 2011.
Lewis, W. M., Melack, J. M., McDowell, W. H., McClain, M., and Richey, J. E.: Nitrogen yields from undisturbed watersheds in the Americas, Biogeochemistry, 46, 149-162, https://doi.org/10.1007/BF01007577, 1999.

Li, C., Farahbakhshazad, N., Jaynes, D. B., Dinnes, D. L., Salas, W., and McLaughlin, D.: Modeling nitrate leaching with a biogeochemical model modified based on observations in a row-crop field in Iowa, Ecol. Model., 196, 116-130, https://doi.org/10.1016/j.ecolmodel.2006.02.007, 2006.

Lovett, G. M. and Goodale, C. L.: A New Conceptual Model of Nitrogen Saturation Based on Experimental Nitrogen Addition to an Oak Forest, Ecosystems, 14, 615-631, https://doi.org/10.1007/s10021-011-9432-z, 2011.

Lükewille, A. and Wright, R.: Experimentally increased soil temperature causes release of nitrogen at a boreal forest catchment in southern Norway, Glob. Change Biol., 3, 13-21, https://doi.org/10.1046/j.1365-2486.1997.00088.x, 1997.

Matson, P., Lohse, K. A., and Hall, S. J.: The Globalization of Nitrogen Deposition: Consequences for Terrestrial Ecosystems, AMBIO J. Hum. Environ., 31, 113-119, https://doi.org/10.1579/0044-7447-31.2.113, 2002.

Matson, P. A., McDowell, W. H., Townsend, A. R., and Vitousek, P. M.: The globalization of $\mathrm{N}$ deposition: ecosystem consequences in tropical environments, Biogeochemistry, 46, 67-83, https://doi.org/10.1023/A:1006152112852, 1999.

Melillo, J. M., Butler, S., Johnson, J., Mohan, J., Steudler, P., Lux, H., Burrows, E., Bowles, F., Smith, R., Scott, L., Vario, C., Hill, T., Burton, A., Zhou, Y.-M., and Tang, J.: Soil warming, carbon-nitrogen interactions, and forest carbon budgets, P. Natl. Acad. Sci. USA, 108, 9508-9512, https://doi.org/10.1073/pnas.1018189108, 2011.

Meyerholt, J. and Zaehle, S.: The role of stoichiometric flexibility in modelling forest ecosystem responses to nitrogen fertilization, New Phytol., 208, 1042-1055, https://doi.org/10.1111/nph.13547, 2015.

Mitchell, T. D. and Jones, P. D.: An improved method of constructing a database of monthly climate observations and associated high-resolution grids, Int. J. Climatol., 25, 693-712, https://doi.org/10.1002/joc.1181, 2005.

Nevison, C., Hess, P., Riddick, S., and Ward, D.: Denitrification, leaching, and river nitrogen export in the Community Earth System Model, J. Adv. Model. Earth Syst., 8, 272-291, https://doi.org/10.1002/2015MS000573, 2016.

Norby, R. J. and Zak, D. R.: Ecological Lessons from FreeAir $\mathrm{CO}_{2}$ Enrichment (FACE) Experiments, Annu. Rev. Ecol. Evol. S., 42, 181-203, https://doi.org/10.1146/annurev-ecolsys102209-144647, 2011.

Olin, S., Schurgers, G., Lindeskog, M., Wårlind, D., Smith, B., Bodin, P., Holmér, J., and Arneth, A.: Modelling the response of yields and tissue $\mathrm{C}: \mathrm{N}$ to changes in atmospheric $\mathrm{CO}_{2}$ and $\mathrm{N}$ management in the main wheat regions of western Europe, Biogeosciences, 12, 2489-2515, https://doi.org/10.5194/bg-122489-2015, 2015.

Parton, W. J., Scurlock, J. M. O., Ojima, D. S., Gilmanov, T. G., Scholes, R. J., Schimel, D. S., Kirchner, T., Menaut, J.-C., Seastedt, T., Garcia Moya, E., Kamnalrut, A., and Kinyamario, J. I.: Observations and modeling of biomass and soil organic matter dynamics for the grassland biome worldwide, Global Biogeochem. Cy., 7, 785-809, https://doi.org/10.1029/93GB02042, 1993. 
Patil, R. H., Laegdsmand, M., Olesen, J. E., and Porter, J. R.: Effect of soil warming and rainfall patterns on soil $\mathrm{N}$ cycling in Northern Europe, Agr. Ecosyst. Environ., 139, 195-205, https://doi.org/10.1016/j.agee.2010.08.002, 2010.

Perakis, S. S. and Hedin, L. O.: Nitrogen loss from unpolluted South American forests mainly via dissolved organic compounds, Nature, 415, 416-419, https://doi.org/10.1038/415416a, 2002.

Piao, S., Sitch, S., Ciais, P., Friedlingstein, P., Peylin, P., Wang, X., Ahlström, A., Anav, A., Canadell, J. G., Cong, N., Huntingford, C., Jung, M., Levis, S., Levy, P. E., Li, J., Lin, X., Lomas, M. R., Lu, M., Luo, Y., Ma, Y., Myneni, R. B., Poulter, B., Sun, Z., Wang, T., Viovy, N., Zaehle, S., and Zeng, N.: Evaluation of terrestrial carbon cycle models for their response to climate variability and to $\mathrm{CO}_{2}$ trends, Glob. Change Biol., 19, 2117-2132, https://doi.org/10.1111/gcb.12187, 2013.

Rabalais, N. N.: Nitrogen in Aquatic Ecosystems, AMBIO J. Hum. Environ., 31, 102-112, https://doi.org/10.1579/00447447-31.2.102, 2002.

Rustad, L., Campbell, J., Marion, G., Norby, R., Mitchell, M., Hartley, A., Cornelissen, J., Gurevitch, J., and GCTENEWS: A meta-analysis of the response of soil respiration, net nitrogen mineralization, and aboveground plant growth to experimental ecosystem warming, Oecologia, 126, 543-562, https://doi.org/10.1007/s004420000544, 2001.

Schlesinger, W. H.: On the fate of anthropogenic nitrogen, P. Natl. Acad. Sci. USA, 106, 203-208, https://doi.org/10.1073/pnas.0810193105, 2009.

Schmidt, I. K., Tietema, A., Williams, D., Gundersen, P., Beier, C., Emmett, B. A., and Estiarte, M.: Soil Solution Chemistry and Element Fluxes in Three European Heathlands and Their Responses to Warming and Drought, Ecosystems, 7, 638-649, https://doi.org/10.1007/s10021-004-0217-5, 2004.

Schultz, M. G., Heil, A., Hoelzemann, J. J., Spessa, A., Thonicke, K., Goldammer, J. G., Held, A. C., Pereira, J. M. C., and van het Bolscher, M.: Global wildland fire emissions from 1960 to 2000, Global Biogeochem. Cy., 22, GB2002, https://doi.org/10.1029/2007GB003031, 2008.

Smith, B., Prentice, I. C., and Sykes, M. T.: Representation of vegetation dynamics in the modelling of terrestrial ecosystems: comparing two contrasting approaches within European climate space, Glob. Ecol. Biogeogr., 10, 621-637, https://doi.org/10.1046/j.1466-822X.2001.t01-1-00256.x, 2001.

Smith, B., Wårlind, D., Arneth, A., Hickler, T., Leadley, P., Siltberg, J., and Zaehle, S.: Implications of incorporating $\mathrm{N}$ cycling and $\mathrm{N}$ limitations on primary production in an individualbased dynamic vegetation model, Biogeosciences, 11, 20272054, https://doi.org/10.5194/bg-11-2027-2014, 2014.

Sullivan, B. W., Smith, W. K., Townsend, A. R., Nasto, M. K., Reed, S. C., Chazdon, R. L., and Cleveland, C. C.: Spatially robust estimates of biological nitrogen $(\mathrm{N})$ fixation imply substantial human alteration of the tropical N cycle, P. Natl. Acad. Sci. USA, 111, 8101-8106, https://doi.org/10.1073/pnas.1320646111, 2014.

Thonicke, K., Venevsky, S., Sitch, S., and Cramer, W.: The role of fire disturbance for global vegetation dynamics: coupling fire into a Dynamic Global Vegetation Model, Global Ecol. Biogeogr., 10, 661-677, https://doi.org/10.1046/j.1466822X.2001.00175.x, 2001.
Tramontana, G., Jung, M., Schwalm, C. R., Ichii, K., Camps-Valls, G., Ráduly, B., Reichstein, M., Arain, M. A., Cescatti, A., Kiely, G., Merbold, L., Serrano-Ortiz, P., Sickert, S., Wolf, S., and Papale, D.: Predicting carbon dioxide and energy fluxes across global FLUXNET sites with regression algorithms, Biogeosciences, 13, 4291-4313, https://doi.org/10.5194/bg-13-42912016, 2016.

van Aardenne, J. A., Dentener, F. J., Olivier, J. G. J., Goldewijk, C. G. M. K., and Lelieveld, J.: A $1^{\circ} \times 1^{\circ}$ resolution data set of historical anthropogenic trace gas emissions for the period 1890-1990, Global Biogeochem. Cy., 15, 909-928, https://doi.org/10.1029/2000GB001265, 2001.

van der Werf, G. R., Randerson, J. T., Giglio, L., Collatz, G. J., Mu, M., Kasibhatla, P. S., Morton, D. C., DeFries, R. S., Jin, Y., and van Leeuwen, T. T.: Global fire emissions and the contribution of deforestation, savanna, forest, agricultural, and peat fires (1997-2009), Atmos. Chem. Phys., 10, 11707-11735, https://doi.org/10.5194/acp-10-11707-2010, 2010.

van Drecht, G., Bouwman, A. F., Knoop, J. M., Beusen, A. H. W., and Meinardi, C. R.: Global modeling of the fate of nitrogen from point and nonpoint sources in soils, groundwater, and surface water, Global Biogeochem. Cy., 17, 26, https://doi.org/10.1029/2003GB002060, 2003.

van Egmond, K., Bresser, T., and Bouwman, L.: The European Nitrogen Case, AMBIO J. Hum. Environ., 31, 72-78, https://doi.org/10.1579/0044-7447-31.2.72, 2002.

Veldhuis, M. P., Hulshof, A., Fokkema, W., Berg, M. P., and Olff, H.: Understanding nutrient dynamics in an African savanna: local biotic interactions outweigh a major regional rainfall gradient, J. Ecol., 104, 913-923, https://doi.org/10.1111/13652745.12569, 2016.

Velthof, G. L., Oudendag, D., Witzke, H. P., Asman, W. A. H., Klimont, Z., and Oenema, O.: Integrated Assessment of Nitrogen Losses from Agriculture in EU-27 using MITERRA-EUROPE, J. Environ. Qual., 38, 402-417, https://doi.org/10.2134/jeq2008.0108, 2009.

Vitousek, P. and Howarth, R.: Nitrogen limitation on land and in the sea: How can it occur?, Biogeochemistry, 13, 87-115, https://doi.org/10.1007/BF00002772, 1991.

Vitousek, P. M., Cassman, K., Cleveland, C., Crews, T., Field, C. B., Grimm, N. B., Howarth, R. W., Marino, R., Martinelli, L., Rastetter, E. B., and Sprent, J. I.: Towards an ecological understanding of biological nitrogen fixation, Biogeochemistry, 57, 145, https://doi.org/10.1023/A:1015798428743, 2002.

Vitousek, P. M., Menge, D. N. L., Reed, S. C., and Cleveland, C. C.: Biological nitrogen fixation: rates, patterns and ecological controls in terrestrial ecosystems, Philos. T. R. Soc. B, 368, 20130119, https://doi.org/10.1098/rstb.2013.0119, 2013.

Wang, C., Houlton, B. Z., Dai, W., and Bai, E.: Growth in the global $\mathrm{N}_{2}$ sink attributed to $\mathrm{N}$ fertilizer inputs over 1860 to 2000, Sci. Total Environ., 574, 1044-1053, https://doi.org/10.1016/j.scitotenv.2016.09.160, 2017.

Wang, Y. P., Law, R. M., and Pak, B.: A global model of carbon, nitrogen and phosphorus cycles for the terrestrial biosphere, Biogeosciences, 7, 2261-2282, https://doi.org/10.5194/bg-7-22612010, 2010.

Wårlind, D., Smith, B., Hickler, T., and Arneth, A.: Nitrogen feedbacks increase future terrestrial ecosystem carbon uptake in an 
individual-based dynamic vegetation model, Biogeosciences, 11 , 6131-6146, https://doi.org/10.5194/bg-11-6131-2014, 2014.

Wolf, A., Ciais, P., Bellassen, V., Delbart, N., Field, C. B., and Berry, J. A.: Forest biomass allometry in global land surface models, Global Biogeochem. Cy., 25, GB3015, https://doi.org/10.1029/2010GB003917, 2011.

$\mathrm{Xu}-\mathrm{Ri}$ and Prentice, I. C.: Terrestrial nitrogen cycle simulation with a dynamic global vegetation model, Glob. Change Biol., 14, 1745-1764, https://doi.org/10.1111/j.1365-2486.2008.01625.x, 2008.

Zaehle, S. and Dalmonech, D.: Carbon-nitrogen interactions on land at global scales: current understanding in modelling climate biosphere feedbacks, Curr. Opin. Environ. Sustain., 3, 311-320, https://doi.org/10.1016/j.cosust.2011.08.008, 2011.

Zaehle, S., Friend, A. D., Friedlingstein, P., Dentener, F., Peylin, P., and Schulz, M.: Carbon and nitrogen cycle dynamics in the O$\mathrm{CN}$ land surface model: 2 . Role of the nitrogen cycle in the historical terrestrial carbon balance, Global Biogeochem. Cy., 24, GB1006, https://doi.org/10.1029/2009GB003522, 2010.
Zaehle, S., Medlyn, B. E., De Kauwe, M. G., Walker, A. P., Dietze, M. C., Hickler, T., Luo, Y., Wang, Y.-P., El-Masri, B., Thornton, P., Jain, A., Wang, S., Wårlind, D., Weng, E., Parton, W., Iversen, C. M., Gallet-Budynek, A., McCarthy, H., Finzi, A., Hanson, P. J., Prentice, I. C., Oren, R., and Norby, R. J.: Evaluation of 11 terrestrial carbon-nitrogen cycle models against observations from two temperate Free-Air $\mathrm{CO}_{2}$ Enrichment studies, New Phytol., 202, 803-822, https://doi.org/10.1111/nph.12697, 2014.

Zhang, J., Tian, P., Tang, J., Yuan, L., Ke, Y., Cai, Z., Zhu, B., and Müller, C.: The characteristics of soil $\mathrm{N}$ transformations regulate the composition of hydrologic $\mathrm{N}$ export from terrestrial ecosystem: Soil $\mathrm{N}$ cycle regulate hydrologic N loss, J. Geophys. Res.-Biogeo., 121, 1409-1419, https://doi.org/10.1002/2016JG003398, 2016. 